\title{
Assessment of Biofortification Approaches Used to Improve Micronutrient-Dense Plants That Are a Sustainable Solution to Combat Hidden Hunger
}

\author{
Esra Koç ${ }^{1}$ (I) $\cdot$ Belgizar Karayiğit ${ }^{1}$ (I)
}

Received: 20 July 2021 / Accepted: 18 October 2021 / Published online: 4 November 2021

( ) The Author(s) under exclusive licence to Sociedad Chilena de la Ciencia del Suelo 2021

\begin{abstract}
Malnutrition causes diseases, immune system disorders, deterioration in physical growth, mental development, and learning capacity worldwide. Micronutrient deficiency, known as hidden hunger, is a serious global problem. Biofortification is a cost-effective and sustainable agricultural strategy for increasing the concentrations or bioavailability of essential elements in the edible parts of plants, minimizing the risks of toxic metals, and thus reducing malnutrition. It has the advantage of delivering micronutrient-dense food crops to a large part of the global population, especially poor populations. Agronomic biofortification and biofertilization, traditional plant breeding, and optimized fertilizer applications are more globally accepted methods today; however, genetic biofortification based on genetic engineering such as increasing or manipulating (such as CRISPR-Cas9) the expression of genes that affect the regulation of metal homeostasis and carrier proteins that serve to increase the micronutrient content for higher nutrient concentration and greater productivity or that affect bioavailability is also seen as a promising high-potential strategy in solving this micronutrient deficiency problem. Data that micronutrients can help strengthen the immune system against the COVID-19 pandemic and other diseases has highlighted the importance of tackling micronutrient deficiencies. In this study, biofortification approaches such as plant breeding, agronomic techniques, microbial fertilization, and some genetic and nanotechnological methods used in the fight against micronutrient deficiency worldwide were compiled.
\end{abstract}

Keywords Biofertilizer · Climate change · COVID-19 · CRISPR/Cas9 · Genetic improvement · Nanoencapsulation

\section{Introduction}

Insufficient energy intake and inability to reconstruct body tissues as a taking less than the required amount of any nutrient is called undernourishment. Today, more than 820 million people in the world are hungry, two billion people are suffering from micronutrient deficiencies and 2 billion people are overweight or obese (FAO 2019; UNEP 2021). Undernutrition and micronutrient deficiencies contribute substantially to the global burden of disease; people have micronutrient deficiencies for at least one including iron $(\mathrm{Fe})$, zinc $(\mathrm{Zn})$, iodine (I), selenium (Se), calcium $(\mathrm{Ca})$, and vitamins such as folate and vitamin A (Beal et al. 2017;

Esra Koç

ekoc@ @sience.ankara.edu.tr; esrakoc.es@gmail.com

1 Department of Biology, Faculty of Science, Ankara University, Ankara, Turkey
FAO 2020a, b; Kumssa et al. 2015; World Health Organization (WHO) and UNICEF 2017) (Fig. 1). Fe deficiency is seen in $20-25 \%$ of the world population and $\mathrm{Zn}$ deficiency is seen in $17.3 \%$ (Cooper et al. 2012). Fe and $\mathrm{Zn}$ are two important nutrients in human nutrition and they are among the most common micronutrient deficiencies in the world. $\mathrm{Zn}$ deficiency is a serious health problem and is common in South Asian and sub-Saharan African countries (Shahzad et al. 2014; Shekari et al. 2015) (Fig. 1). Furthermore, 2 billion people suffer from I deficiency (Horton et al. 2008), and 254 million pre-school children have vitamin A deficiency. It was reported that symptoms of night blindness were detected in 5.2 million pre-school children and low serum retinol concentrations were detected in 190 million children due to vitamin A deficiency (Sherwin et al. 2012). Vitamin A and I deficiency are most common in South Asian and sub-Saharan African countries (Stevens et al. 2015; Zimmermann 2009) (Fig. 1). Moreover, I deficiency is seen in more developed regions such as Europe, the USA, and 
Fig. 1 Prevalence of undernourishment (based on FAO 2020a, b) and zinc deficiency (based on ECA 2015; Gupta et al. 2020;

Wessells and Brown 2012),

WHO geographic distribution of anemia prevalence (based on WHO 2019), and estimated prevalence of vitamin A deficiency (based on Stevens et al. 2015)
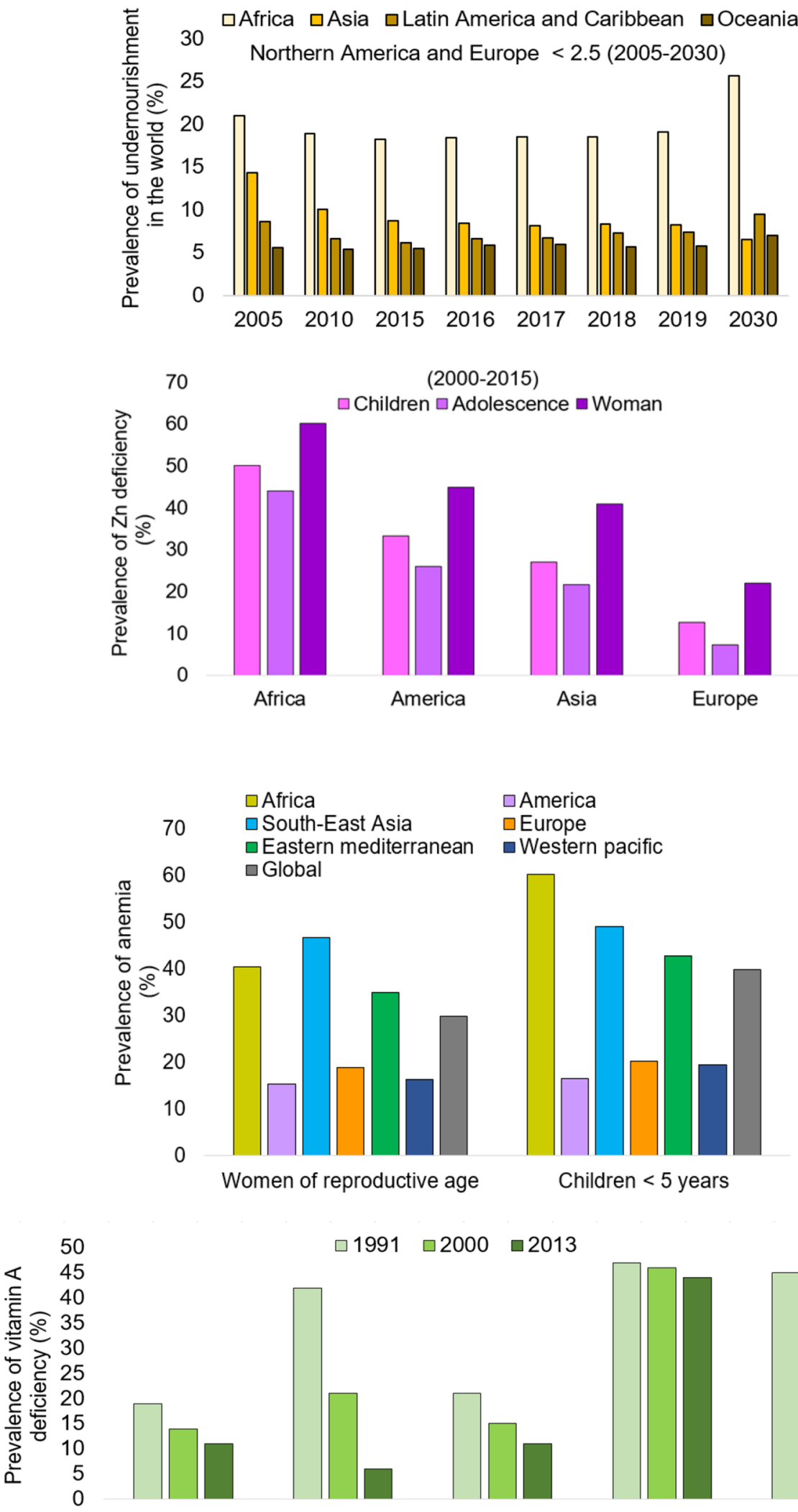

50
45
40
35
30
25
20
15
10
5
0

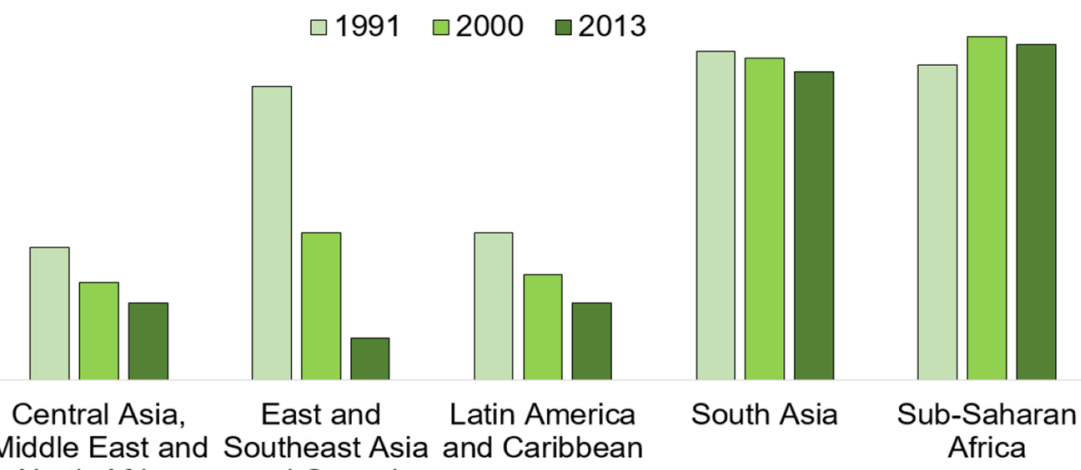


Australia more mildly (Zimmermann 2009). I deficiency leads to stillbirth, cretinism, goiter, thyroid inflammation, and impaired cognitive development (Landini et al. 2011). Vitamin A, Zn, Fe, and I deficiencies were reported to cause deaths in approximately $20 \%$ of children aged under five (Prentice et al. 2008; Stewart et al. 2010). Anemia is also seen in approximately $24.8 \%$ of the world's population (mostly common in South Asian and sub-Saharan African countries) and the most common causes include nutrient deficiencies such as Fe deficiency, as well as vitamin B12 and vitamin A deficiencies (Chaparro and Suchdev 2019; WHO 2021) (Fig. 1). Deficiency of Se (especially in China, Africa, and Northern Europe), another micronutrient, affects $0.5-1.0$ billion people worldwide and can be prevented by dietary supplementation containing Se in "Keshan disease," a fatal cardiomyopathy disease in humans (Alloway 2013).

Micronutrient deficiencies, which threaten human health, are directly and indirectly related to all environmental factors. Factors such as low or high light and temperature, excessive rain, high $\mathrm{CO}_{2}$, flooding, pathogenic diseases, soil type, and the antagonistic effects of micronutrients $(\mathrm{Cu}-\mathrm{Zn}$, $\mathrm{Fe}-\mathrm{Cu}, \mathrm{Fe}-\mathrm{Mn}, \mathrm{Cu}-\mathrm{Mn}$ ) lead to micronutrient deficiency in plants (Giri et al. 2017; Liu et al. 2014; Moraghan and Mascagni 1991; Neenu and Ramesh 2020). Micronutrient deficiencies are global phenomena that are seen in soils ranging from neutral to alkaline, as well as soils with anaerobic conditions in arid regions (Kalra et al. 2020; Monreal et al. 2015; Voortman and Bindraban 2015). The critical concentrations of micronutrients in soils vary based on the soil test procedure, product, soil type, and soil $\mathrm{pH}$. Soils in regions with arid climates are generally alkaline with high soil $\mathrm{pH}$, while soils in regions with humid climates are generally acidic with low pH (Brady and Weil 2002). Soil pH is one of the most important factors controlling the availability of all plant nutrients, microbial activity, and crop growth (Zhang et al. 2019). Temperature and amount of precipitation change soil $\mathrm{pH}$ by affecting the intensity of leaching and soil mineral weathering. Micronutrient availability generally decreases as soil $\mathrm{pH}$ increases, with the exception of Mo. High $\mathrm{pH}$ and $\mathrm{CaCO}_{3}$, low organic matter content and soil moisture, and flooding-induced electrochemical changes are the main factors of low $\mathrm{Zn}$ availability in plants (Graham 2004). Silica and calcareous sandy soils with neutral or alkaline $\mathrm{pH}$ cause $\mathrm{Mn}$ immobility, which leads to $\mathrm{Mn}$ deficiency in plants (Rengel 2000). With increasing pH, the solubility of free Fe decreases 1000-fold, which reduces the availability of $\mathrm{Fe}$ in alkaline and calcareous soils $(\mathrm{pH}>7)$ (Hiradate et al. 2007). The calcareous soils common in the arid areas of the world are poor in micronutrients such as $\mathrm{Fe}$ and $\mathrm{Zn}$ (FAO 2016).

Soil moisture and temperature are important for the uptake of micronutrients. Low temperature and humidity affect the micronutrient availability causing a decrease in root activity, dissolution rates, and nutrient diffusion. In addition, wet soil conditions at low temperature further reduce the availability of micronutrient cations (Choudhary and Suri 2014; Kumar et al. 2016). Low soil temperature decreases the production of phytosiderophores and mobilization and uptake of soil Fe by Gramineae members, while high soil temperature decreases Fe uptake by increasing the microbial decomposition of phytosiderophores and stimulating $\mathrm{CO}_{2}$ production (Marschner et al. 1986).

Climatic change, which is a result of the increase in greenhouse gases, causes decreases in crop production, yield, and quality, and thus nutritional deficiency in humans (Myers et al. 2014). Increasing temperature with climate change and changes in precipitation amount and density affect the leaching density and soil minerals, and cause changes in soil pH (Abdalla and Smith 2016). MorenoJiménez et al. (2019) stated that increasing drought, which is also a result of climatic change, will limit the availability of essential micronutrients, especially $\mathrm{Fe}$ and $\mathrm{Zn}$. The findings showed that aridity negatively affected the uptake of $\mathrm{Cu}, \mathrm{Fe}, \mathrm{Mn}$, and $\mathrm{Zn}$ by reducing soil $\mathrm{pH}$ and organic matter. Heat stress causes deterioration in root activity (such as nutrient-uptake proteins), reducing the concentration of nutrients in plant tissues (Heckathorn et al. 2014). Giri et al. (2017) reported that nutrient uptake and assimilation protein levels decreased in tomato roots exposed to severe heat stress $\left(40-42{ }^{\circ} \mathrm{C}\right)$. For this reason, they pointed out that increases in heat stress with global warming may reduce crop production and nutrient quality due to its negative effect on rootnutrient relationship.

It is known that increased $\mathrm{CO}_{2}$, another factor that negatively affects plant nutrient content, causes a decrease in $\mathrm{Zn}$ and $\mathrm{Fe}$ concentrations in plants such as wheat and rice (Myers et al. 2014). High $\mathrm{CO}_{2}$ alters the balance of plant carbon metabolism and mineral composition and nutrientuse efficiency. In a recent study, the effect of increased $\mathrm{CO}_{2}$ on the intake of $\mathrm{Fe}, \mathrm{Zn}$, and protein for the populations of 151 countries was investigated. The results reveal that countries in North Africa, south and Southeast Asia and the Middle East, and sub-Saharan Africa are among the hardest hit. Considering the population of 2050 and the $\mathrm{CO}_{2}$ ratio $(\sim 550 \mathrm{ppm})$, it is estimated that increased $\mathrm{CO}_{2}$ could cause $\mathrm{Zn}$ deficiency in an additional 175 million people and $\mathrm{Fe}$ deficiency in 311 million children ( $0-4$ years old). In addition, 122 more million people could be added to the 622 million who do not receive enough protein (Smith and Myers 2018). Smith and Myers (2019) reported that $\mathrm{CO}_{2}$, which would increase further until 2050, may cause a $17-30 \%$ decrease in the amounts of vitamins such as thiamin, riboflavin, and folate in rice.

Changes in climatic parameters alter the susceptibility of crops to pathogens, resulting in changes in their physiological and normal functions, reduced biosynthetic capacity, and 
eventual plant death. This decline in agricultural production and product yield and quality is one of the most important obstacles to achieving the goal of feeding the starving population on a global scale (Dong and Ronald 2019). In addition, climate change can facilitate the spread of many pathogens, including viruses, localized in certain regions due to geographical barriers and climate constraints (Savo et al. 2016). It has been reported that climate change may cause gradual substitution of species, decrease in species diversity, and shrinking of ecosystems (Nunez et al. 2019). These and similar changes may lead to increased contact between wildlife and humans (Rodó et al. 2021). Therefore, global warming poses a great risk in the spread of existing infectious diseases and the emergence of those that are not yet seen.

Despite the warnings of scientists that the climate crisis should be taken seriously and numerous international agreements (Montreal Protocol, UN Framework Convention on Climate Change, Kyoto Protocol, Paris Climate Agreement, etc.), countries have delayed in taking adequate and necessary measures to reduce carbon emissions. Therefore, various policies and strategies (reducing emissions, green technology, etc.) need to be put into effect urgently to reduce greenhouse gas emissions and limit the $\mathrm{CO}_{2}$ impact, before it is too late.

The critical deficiency levels of micronutrients in crop plants are generally in the range between 1 and 5 for $\mathrm{Cu}$, 50-100 for Fe, 15-20 for Zn, and 10-20 for Mn (mg kg-1 DM) (Alloway 2013). Most plants can accumulate micronutrients whereas some main crops, particularly the edible parts of plants, contain insufficient amounts of $\mathrm{Fe}$ and $\mathrm{Zn}$ (Wakeel et al. 2018). Basic crops such as rice, wheat, and maize contain low amounts of $\mathrm{Zn}$ and $\mathrm{Fe}$ (Shariatipour and Heidari 2020). Processing cereals before consumption is another factor that reduces their micronutrient content. The presence of large amounts of micronutrients such as Fe and $\mathrm{Zn}$ in parts other than the endosperm, which are lost during procedures (milling, polishing, etc.) (Ozturk et al. 2006) and the rare measurement of toxic elements such as cadmium (Cd) and arsenic (As), which threatens food safety, are considered an important problem. $\mathrm{Zn}$ and Fe were mostly localized to the aleurone layer of the wheat grain. Consumption of the wheat grain, usually by milling, results in the removal of the Zn-rich parts, leaving behind the Zn-poor endosperm. It is also known that $75 \%$ of folate is lost in whole wheat during this process. Cakmak et al. (2010b) reported that the amount of $\mathrm{Zn}$ in white flour does not meet the requirements for daily diet. In addition, compounds such as phytate localized to the aleurone layer of wheat and rice aggravate this problem by reducing the bioavailability in terms of $\mathrm{Zn}$. During milling, about $90 \%$ of the phytic acid is removed from the cereal grains, but the remaining $10 \%$ still acts as a potent inhibitor (Dary and Hurrell 2006). The B vitamin and Fe are mostly found in the germ and bran layers of rice, and therefore significant losses occur during the milling process. For example, it has been reported that $80 \%$ of the thiamine amount is removed during the milling of brown rice into white rice. In addition, other nutrients such as niacin, $\mathrm{Fe}$, and riboflavin in the bran layer are also lost (Abbas et al. 2011). Polished grains are more preferred because the removal of insoluble fibers by polishing facilitates cooking, chewing, and digestion. This process also extends the shelf life of grain but induced important losses in mineral content. Proteins, fats, minerals, and vitamins in the outer grain layers are denser than the inner parts, but polishing causes a significant decrease in the concentration of mineral elements in the grain (Hansen et al. 2012). It has been reported that there was a significant reduction in the amount of micronutrients such as $\mathrm{Mn}, \mathrm{Zn}, \mathrm{Ni}, \mathrm{Cu}, \mathrm{Fe}$, and thiamine in polished rice (Pourcel et al. 2013; Yao et al. 2020). For this reason, increasing the micronutrient levels or bioavailability in the edible parts of plants such as the endosperm, which is especially poor in $\mathrm{Fe}$ and $\mathrm{Zn}$, by biofortification is considered a potential sustainable strategy in the combating against malnutrition.

If minerals are not found in sufficient quantities in the soil, their deficiencies lead to a reduction in product quality and thus deterioration of human health (WHO 2009). The reason for the increasing interest in the problem of micronutrient malnutrition is that it is a public health problem not only in poor countries but also in developed countries (Fig. 1). As mentioned above, I and Fe deficiency, which are the most common micronutrient deficiencies in the world, are also common in European countries. In addition, it has been reported that consumption of foods rich in energy but insufficient in terms of micronutrients negatively affects micronutrient intake in industrialized countries (Allen et al. 2006).

Micronutrients are essential for their vital physiological functions, and their deficiency causes serious health disorders. $\mathrm{Zn}$ is a micronutrient that is effective in many events such as reproduction and neurotransmission, especially the immune system. Its deficiency causes learning impairment, physical growth and reproductive health, a decrease in immune resistance, and an increase in the rate of infection (Verma et al. 2021; Wessels and Rink 2020). Fe acts as an important cofactor for various enzymes involved in plant and human metabolism. its deficiency causes deterioration in the immune system and anemia. Inadequacy of essential micronutrients such as vitamins $\mathrm{A}$ and $\mathrm{D}, \mathrm{Fe}, \mathrm{Se}, \mathrm{Cu}$, and $\mathrm{Zn}$ may cause an insufficient immune system against viral and bacterial infections (Bae and Kim 2020). For example, due to the antiviral and immune-enhancing properties of $\mathrm{Se}$ and $\mathrm{Zn}$, it has been reported to be effective in reducing symptoms against SARS-CoV-2 infection (Zhang et al. 2020). It is seen how critically important micronutrients are in the 
formation of a well-functioning immune system during the COVID-19 pandemic (WHO 2020). The recent research shows that the essential nutrients like vitamin A, vitamin B (folate, vitamin B6, and vitamin B12), vitamin C, vitamin $\mathrm{D}$, and the minerals such as $\mathrm{Fe}, \mathrm{Cu}, \mathrm{Se}$, and $\mathrm{Zn}$ can help strengthen people's resilience to the COVID-19 pandemic (Cámara et al. 2021; Richardson and Lovegrove 2021; Wessels and Rink 2020). The antiviral property of $\mathrm{Cu}$ is attributed to its regulatory role on some enzymes that are critical to the functions of immune cells (Gombart et al. 2020). It has been reported that vitamins $\mathrm{A}, \mathrm{D}, \mathrm{E}$, and $\mathrm{K}$ strengthen the body's defense mechanism against COVID-19 infection and prevent complications such as cytokine storm (Samad et al. 2021). A recent study has shown that vitamin D supplementation can play an important role in the treatment of COVID-19 patients (Sooriyaarachchi et al. 2021). In another study, a high prevalence of vitamin D deficiency was seen in countries such as Italy, Spain, and France, which have higher COVID-19 mortality rates compared to other European countries (Kehoe et al. 2019). Vitamin $C$ has been proposed as an effective agent in improving the neutrophil response, which is responsible for the high cytokine levels produced during the cytokinin storm (Colunga Biancatelli et al. 2020). Data from a previous study showed that vitamin $E$ and Se are effective on the control of viral replication and mutations, and that RNA viruses can convert more virulent strains in case of malnutrition from these micronutrients (Beck et al. 1995). It has been found that there is a direct relationship between Se deficiency and lower recovery rates in COVID-19 cases, and that Se is effective in reducing the risk of COVID-19 by inactivating the viral spike protein (Kieliszek and Lipinski 2020; Zhang et al. 2020). Therefore, it has been suggested that Se supplementation such as $\mathrm{Zn}$ may be a natural treatment to combat the virus in COVID-19 patients with low blood levels (Schiavon et al. 2020). It has been stated that feeding with different crops biofortified in terms of $\mathrm{Se}$ in the human diet can provide Se supplementation (Newman et al. 2019). These results emphasize that regular consumption of foods biofortified in terms of Se can be a sustainable and practical method for human health. Iodine is an essential microelement regulating growth, development, and basal metabolic rate. Derscheid et al. (2014) reported that I could support the innate immune system in the fight against infections. Also, recent data have shown that Japanese, known for their high I intake, have a very low number of COVID-19 deaths compared to other countries. Because it supports the innate immune system, I has been suggested as a therapeutic and preventive agent in the fight against the COVID-19 pandemic (Verheesen and Traksel 2020). Given the positive impact of this micronutrient resistance on human immune function, it is also likely to increase people's resistance to potential future pandemics. Gastélum-Estrada et al. (2021) reported that consumption of biofortified foods (tomato, acerola, mushrooms, wheat, chickpea, etc.) in addition to vaccination would strengthen the immune system and suggested it as a realistic approach that could help reduce the risk of COVID-19 disease.

COVID-19 has caused a decline in household incomes, especially for those living in poor areas (FAO 2020a, b; World Bank 2020). This decrease in income levels has also caused changes in food consumption patterns and increased dependency on basic crops that are more affordable instead of expensive foods (Clapp and Moseley 2020; FAO et al. 2020; Klassen and Murphy 2020; Laborde et al. 2020). On the other hand, biofortified crops will also help poor families survive during crises such as COVID-19 or after natural disasters (droughts, floods, heavy rainfall, cyclones, and pests). In these processes, since vulnerable communities living in poor geographies use basic foods, biofortification is important in terms of ensuring that these people continue to consume valuable minerals and vitamins.

Micronutrient deficiencies increase susceptibility to many infectious diseases, including COVID-19 (Akhtar et al. 2021; Huizar et al. 2021). Therefore, the COVID-19 pandemic, which is a global health crisis that defines our century, has drawn attention to the importance of biofortification, which is an effective strategy to combat micronutrient deficiency. In addition, considering that climatic change may cause hundreds of millions of people to suffer from nutritional deficiencies in the future, it is obvious how important it is to fortify foods. Therefore, the intake of nutritious and adequate micronutrients in daily diets will increase the resilience of the rapidly increasing global population in the face of crises. Biofortification, which is used to improve the nutritional value of plants, is presented as a sustainable solution to overcome many nutritional problems with breeding, microbial, agricultural, or fertilization approaches, as well as genetic engineering and biotechnological strategies (Fig. 2).

\section{The Uptake of Micronutrients}

Optimal uptake of micronutrients from soil solutions is vital since micronutrient deficiencies in crops tend to cause low intakes in the diets of animals and humans. Therefore, the uptake of some micronutrients from the soil has been briefly reviewed. $\mathrm{Fe}$ in the rhizosphere is taken up into root cells by two different strategies based on non-Graminaceae plants (strategy I) and Graminaceae plants (strategy II) (Fig. 3). In strategy I plants, after the soil is acidified by H-ATPase AHA2 and solubilized in the Fe rhizosphere, $\mathrm{Fe}^{3+}$ is reduced to ferrous $\mathrm{Fe}^{2+}$ by ferric chelate reductase (FRO2) and taken into the root epidermal cells by the metal carrier IRT1 (plasma membrane-localized $\mathrm{Fe}^{2+}$ transporter) (Conte and Walker 2011; Ivanov et al. 2012). Some plants 
Fig. 2 Different approaches for biofortification

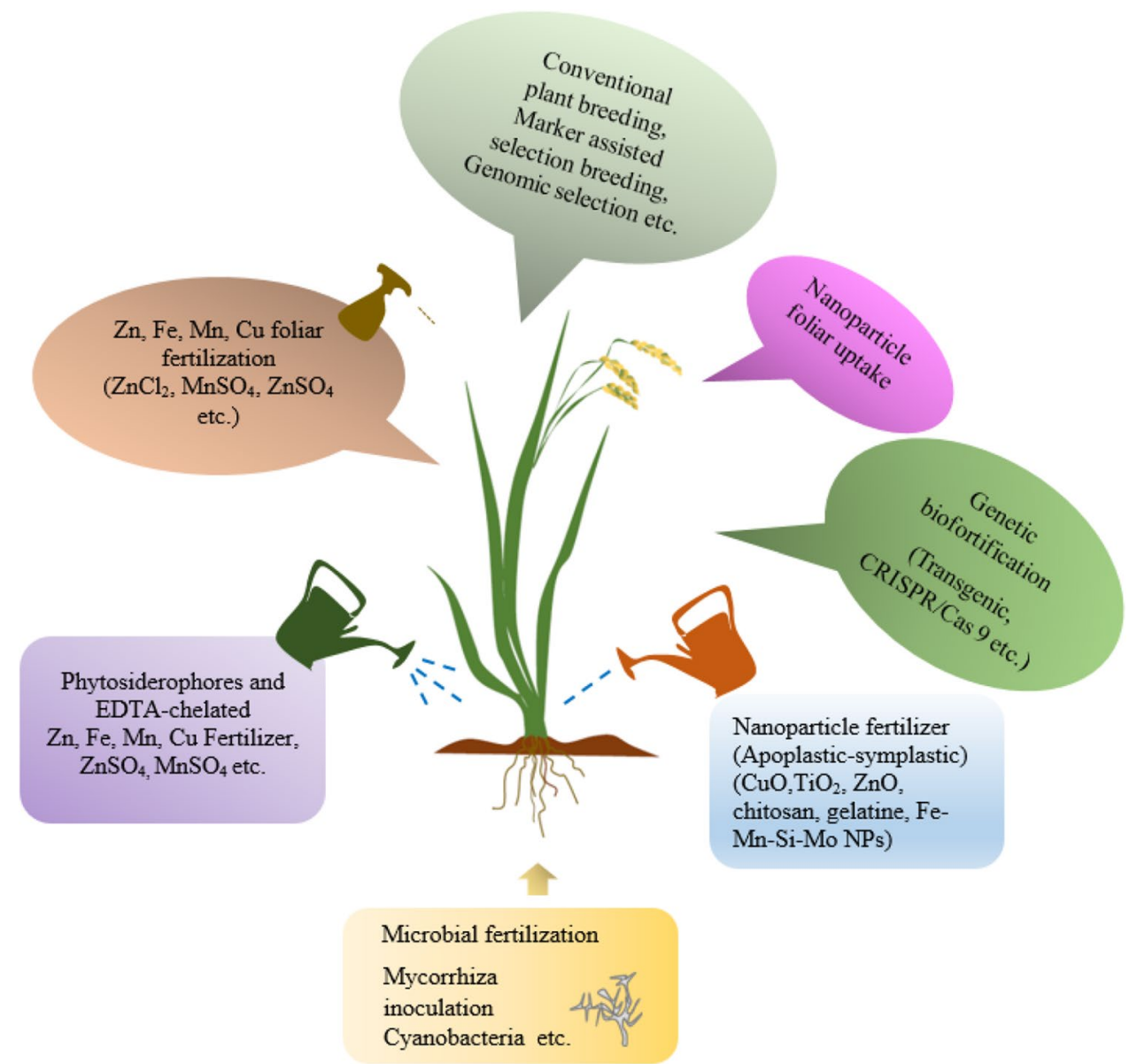

use a chelation strategy to get Fe from the soil. This strategy is based on the phytosiderophore secretion by the roots. In strategy II plants, after substances such as mugineic acid are secreted into the rhizosphere by phytosiderophore transporters, ferric iron $\mathrm{Fe}^{3+}$ is chelated and $\mathrm{Fe}$-phytosiderophore chelates are transported to stem cells by YELLOW-STRIP1 (YSL), a transmembrane peptide transporter localized in the plasma membrane (Curie et al. 2001; Li et al. 2018).

Zn uptake in plants is generally through transmembrane transporters in the ZIP (ZRT and IRT-like protein) family, which are localized in the plasma membrane of root epidermal cells (Tiong et al. 2014). Excess Zn prevents the uptake of $\mathrm{Mn}, \mathrm{Fe}$, and $\mathrm{Cu}$. In $\mathrm{Cu}$ deficiency, plants induce the expression of the gene encoding the transcription factor, SPL7, and a major plasma membrane $\mathrm{Cu}$ uptake transporter, COPT1, to increase $\mathrm{Cu}$ uptake (Fig. 3). As a result of many human activities, including the administration of $\mathrm{Cu}$-containing solutions against some disease-causing pathogens, pollution occurs due to excessive $\mathrm{Cu}$ accumulation in soils. Excess $\mathrm{Cu}$ causes oxidative stress in plants and leads chlorophyll to lose its function by preventing the uptake of other basic metals such as Mg (Karimi et al. 2012). Manganese (Mn) is abundant in the earth and seawater and is taken by plants as $\mathrm{Mn}^{2+}$. The uptake of $\mathrm{Mn}^{2+}$, which is abundant in acidic soils, is carried out by the carrier protein NRAMP1 (also NRAMP 3, 4 in vacuolar membrane, YSL 6 in rice, etc.), which is localized in the plasma membrane in plants (Fig. 2). Mn deficiency is common mostly in alkaline soils. On the other hand, like most metal micronutrients, $\mathrm{Mn}$ is toxic at high concentrations, and in particular, high $\mathrm{Mn}^{2+}$ in acidic soils prevents the uptake of other cations such as Fe. Mo, which is less in the soil, is taken into the plant as $\mathrm{MoO}_{4}{ }^{-2}$ by MOT1 and MOT2 carriers (Tejada-Jiménez et al. 2013).

\section{Biofortification Strategies}

\subsection{Plant Breeding and Agronomic Strategy}

Biofortification is an important strategy to overcome this micronutrient deficiency that threatens human health. Traditional plant breeding is based on the traditional manipulation of plant genomes to improve crops and increase some essential nutrients. Broad research programs such as HarvestPlus and BioCassava Plus used traditional breeding methods to 


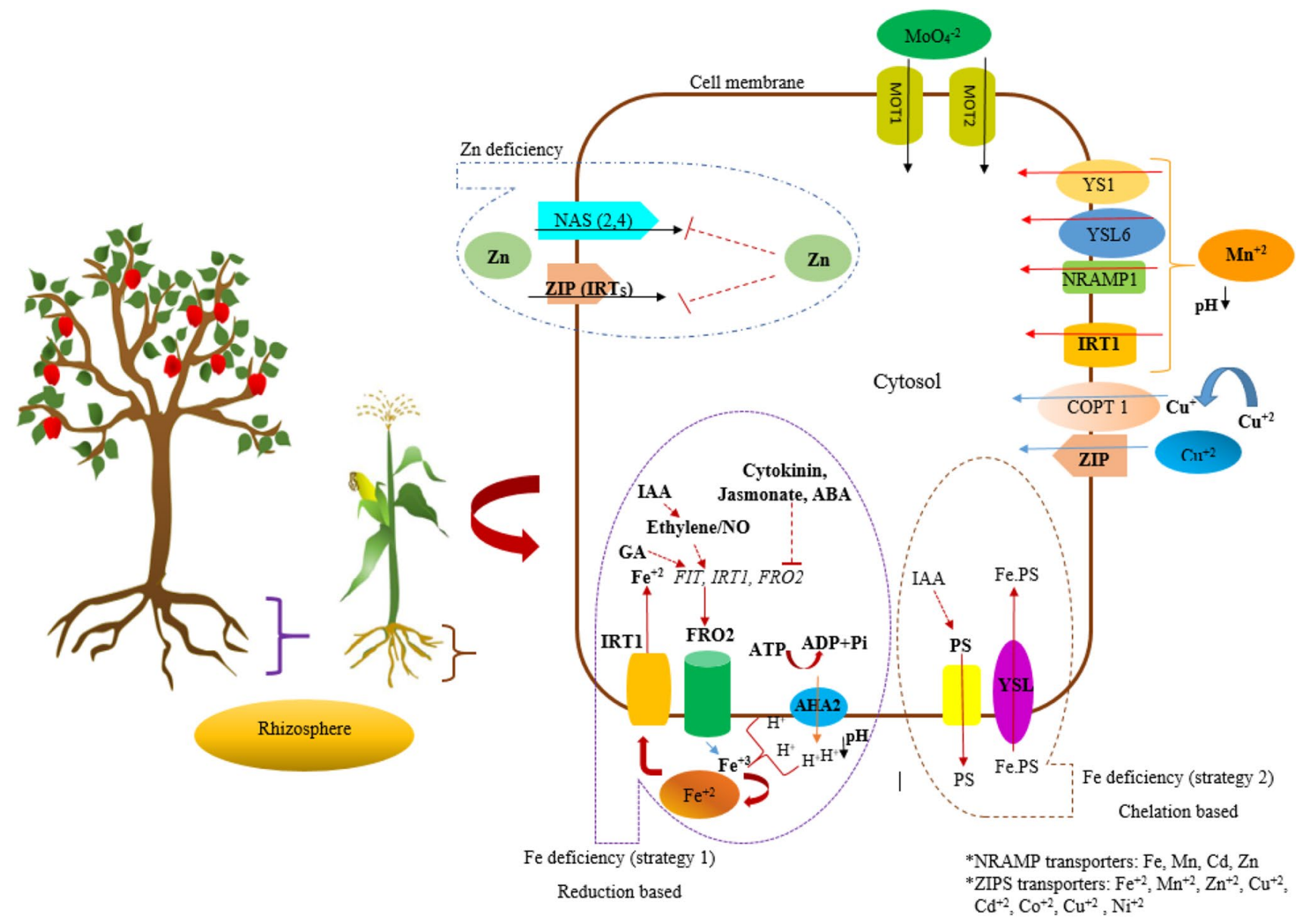

Fig. 3 Uptake mechanism of $\mathrm{Fe}, \mathrm{Zn}, \mathrm{Cu}, \mathrm{Mn}$, and Mo from soil to plant

develop biofortified crops (Garg et al. 2018). Biofortified crops with higher vitamin $\mathrm{A}, \mathrm{Fe}$, and $\mathrm{Zn}$ are also important in maintaining immune systems for vulnerable people whose nutritional diets depend on one or two food products such as corn, rice, and wheat. Therefore, biofortified crop varieties with $\mathrm{Zn}$ and vitamin $\mathrm{A}$ are now available in Africa and Asia. For example, it was reported that increasing the $\beta$-carotene content of Ipomoea batatas L. biofortified by the traditional breeding method reduced vitamin A deficiency in children in South Africa; on the other hand, consuming rice fortified in $\mathrm{Fe}$, which was developed by the HarvestPlus program, increased ferritin in Filipino women (Low et al. 2017).

The agronomic strategy of biofortification is mainly based on the application of mineral fertilizers, particularly $\mathrm{Fe}$ and $\mathrm{Zn}$, in order to increase the solubility and mineral content of micronutrients in the soil (White and Broadley 2009). The effective and proven role of $\mathrm{Zn}$ in boosting the human immune system against viruses and other health threats may be a good reason to grow wheat and rice varieties with high $\mathrm{Zn}$ content. It was reported in the studies that these micronutrient deficiencies in the soil can be eliminated by the fertilization method. An increase in micronutrient concentration and grain yield was reported in areas with micronutrient deficiencies after the application of fertilizer and micronutrient combination to soils and leaves (Cakmak et al. 2010a; Imtiaz et al. 2010). For example, in countries such as Australia, the USA, Canada, and in the European region which have different climate characteristics and micronutrient deficiencies in the soils, fertilizers and micronutrients are applied to the soil to increase the grain crop yield and fruit yield in trees. The effective and proven role of $\mathrm{Zn}$ in boosting the human immune system against viruses and other health threats may be a good reason to grow wheat and rice varieties with high $\mathrm{Zn}$ content. Fe and $\mathrm{Zn}$ fertilization is one of the methods to increase the accumulation and yield of minerals in grains (Alloway 2008). It was determined in the studies that the amount of $\mathrm{Zn}$ and $\mathrm{Fe}$ increases in $\mathrm{Fe}$ - and $\mathrm{Zn}$-applied wheat, rice, and corn (Aref 2010; Stomph et al. 2011). Inorganic Fe fertilization of soils is not practical since $\mathrm{Fe}$ in inorganic $\mathrm{Fe}$ fertilizers is transformed into forms, which cannot be taken by plants, through oxidation and precipitation. Therefore, the use of Fe-chelates 
as Fe fertilizer and acidification of the soil are preferred to increase Fe uptake and access (Wakeel et al. 2018). It was found that the International HarvestPlus biofortification program, which adopts traditional breeding, and foliar Zn application to increase $\mathrm{Zn}$ concentrations in the edible parts of grains such as wheat, corn, and rice in the sub-project study, are more effective than the application to soil and that the highest increase in $\mathrm{Zn}$ amount is achieved in wheat (Cakmak and Kutman 2018; www.harvestzinc.org). Madhaiyan et al. (2010) reported that $\mathrm{Zn}$-solubilizing bacteria increased the $\mathrm{Zn}$ concentration in roots and shoots of wheat and soybean. Green fertilization using nitrogen-fixing plants such as clover, vetch, and broad bean and $\mathrm{Zn}$-coated urea (fertilizer) increase the concentration of $\mathrm{Zn}$ in grain and straw. Pooniya and Shivay (2015) stated that surface fertilization with Znenriched urea provides higher $\mathrm{Zn}$ uptake in basmati rice than fertilization with $\mathrm{ZnSO}_{4}$ in soil applications and that Zn-enriched urea improved productivity and all the quality parameters (physical, chemical, and cooking quality; rice grain length, breath, and their ratio before and after cooking) of Basmati rice. Soil microbiological parameters and yield and quality parameters of rice showed significantly positive correlations. This positive correlation was attributed to the increase in nutrient intake and mobilization.

Rapid urbanization and industrialization are the most important factors causing soil pollution all over the world (Hu et al. 2020). Activities such as mining, traffic, wastewater irrigation, pesticide use, and reuse of sewage sludge cause heavy metal pollution in arable lands (Huang et al. 2016). Therefore, the emission of various heavy metals in agricultural soils changes the ecological function of the soil and endanger human health by accumulating in crops $(\mathrm{Li}$ et al. 2020). In addition, heavy metals can accumulate in the soil due to the application of manure and inorganic fertilizers (Martin et al. 2006). The application of $\mathrm{Zn}$ at proper concentrations in cereals grown in soils with high $\mathrm{Cd}$ content reduces the uptake and accumulation of $\mathrm{Cd}$; however, the continuous use of some micronutrient fertilizers at high concentrations for long term increases the accumulation of toxic metals such as Cd (Shahzad et al. 2014). Cd, which is the most toxic metal for humans and all other living organisms among all heavy metals, is easily taken up by plants due to its high mobility in both soil and plant systems. The presence of $\mathrm{Zn}$ in the soil and in the plant has a vital role in the accumulation of $\mathrm{Cd}$, which is a toxic element because $\mathrm{Zn}$ competes with $\mathrm{Cd}$ for the same membrane transporters, reduces the uptake and accumulation of $\mathrm{Cd}$, and reduces the oxidative damage that will occur in the plant. Other elements that are effective in preventing $\mathrm{Cd}$ accumulation are $\mathrm{Fe}$ and $\mathrm{Mn}$. Fe deficiency can accelerate $\mathrm{Cd}$ accumulation. $\mathrm{Fe}$ and $\mathrm{Mn}$ compete with $\mathrm{Cd}$ for the same membrane transporter and prevent $\mathrm{Cd}$ uptake from the root. Moreover, they reduce the accumulation of $\mathrm{Cd}$ in the crop by preventing the formation of $\mathrm{Fe}$ plaques that adsorb $\mathrm{Cd}$ on the root surface and the reactive oxygen species (ROS) formed in the cell as a cofactor of antioxidant enzymes from damaging the plasma membrane (Liu et al. 2008; Sarwar et al. 2010). Therefore, applying $\mathrm{Fe}$ to $\mathrm{Cd}$-contaminated soils can increase the $\mathrm{Fe}$ concentration in the crop and also decrease the $\mathrm{Cd}$ concentration. On the other hand, in addition to increasing the micronutrients such as $\mathrm{Fe}$ and $\mathrm{Zn}$ in the edible parts of plants by fertilization, it is necessary to recycle micronutrients considering the possibility of increased fertilization costs in the future and environmental concerns. For example, it was determined that $\mathrm{Zn}$ concentration in Triticum aestivum L. species can increase and have similar effects with $\mathrm{ZnCO}_{3}$ when sewage sludge and liquid-treated sludge are applied to soil (McGrath et al. 2012).

It was reported that $\mathrm{Se}$, another micronutrient required in human nutrition, is utilized to develop tolerance against abiotic stresses such as high temperature, freeze, drought, salinity, and heavy metals (Feng et al. 2013). Se not only promotes plant growth and development but also increases the resistance against various abiotic stresses by increasing the capacity of enzymatic antioxidants such as catalase, superoxide dismutase, peroxidase, and non-enzymatic antioxidants such as vitamin $\mathrm{E}$ and ascorbate against oxidative stress caused by ROS (Domokos-Szabolcsy et al. 2017; Hasanuzzaman et al. 2010). Broccoli and garlic are good candidates for biofortification studies since they naturally accumulate Se (Hsu et al. 2011). Agronomic crop biofortification by Se has been considered a cost-effective method for growing wheat with high Se content. The foliar fertilization of wheat with Se or adding it during the soaking process during seed germination are shown as effective alternatives to obtain biofortified foods in terms of Se. In fact, increasing Se content in wheat is a food strategy that increases Se uptake by people (Masarovičová and Králová 2012). Therefore, Se biofortification of foods may be a sustainable and practical method that can increase Se uptake by the human population.

Salt is considered the ideal way for people to eliminate I deficiency for some reasons such as its universal consumption, cheap processing, and the ability of a small number of manufacturing companies to carry out this business (Horton et al. 2008; Zimmermann et al. 2008). The most effective universal strategy to reduce I deficiency is accepted as salt iodization (fortification of consumed salt with I). Therefore, it was reported that the addition of soluble iodide and iodate salts to irrigation water in agriculture can reduce I deficiency by increasing the amount of I in the edible parts of crop plants (Lyons et al. 2004). Furthermore, it was stated that the concentration of I can be increased in plants such as wheat, corn, and rice with surface applications of $\mathrm{KIO}_{3}$. Similar to the results obtained in $\mathrm{Fe}$ and $\mathrm{Zn}$ biofortification studies, the foliar fertilization of I is more effective on I concentration 
than soil applications (Budke et al. 2020; Cakmak et al. 2017). Budke et al. (2020) reported that foliar fertilization of $\mathrm{I}$ is a promising method for biofortifying apples with I. The long-distance transport of I in plants occurs primarily in the xylem, while the mobility in the phloem is estimated to be low (Humphrey et al. 2019). In the study using radioactive I isotope, it has been detected that I can accumulate by penetrating through the stomata and the cuticle of epidermal cells of the leaves (Humphrey et al. 2019). It has been suggested that this is an effective approach to biofortifying leafy vegetables. Cakmak et al. (2017) stated that foliar-applied I was transported to the seed in the head and early milk development stages of some cereal species and diffusion was effective in the accumulation of $I$ in the grain.

\subsection{Microbial Biofertilizers}

The population is rapidly increasing all over the world, and thus the nutritional needs of people are increasing, as well. Due to the increasing nutritional needs, people are trying to obtain more products from the resources they have. Water and soil pollution is one of the most important disadvantages of fertilization. Selective breeding, which is one of the biofortification techniques, is a method used to biofortify the main crops by crossing plant varieties naturally rich in micronutrients (Malik and Maqbool 2020). However, there are some limiting factors in selective breeding such as low heritability and lack of genetic diversity. Plant breeding and agronomic biofortification strategies are difficult to sustain as they require long monitoring and continuous support respectively (Kaur et al. 2020). Therefore, some studies and transgenic programs are carried out in developing countries on the use of different biofertilizers to improve basic crops with micronutrients (Garg et al. 2018; Kaur et al. 2020; Malik and Maqbool 2020). The use of biofertilizers is considered a more advantageous approach because it reduces environmental pollution, is cheap and easy to produce, is sustainable in agriculture, and is easily accessible. Various microorganisms such as bacteria, fungi, cyanobacteria, actinomycetes, and mycorrhizae, expressed by Gadd (2010) as the invisible engineers of the soil, support micronutrient uptake with various properties such as dissolution of micronutrients in the soil, production of phytohormones, nitrogen fixation, and oxidation and chelation and improve plant growth (Rana et al. 2020; Yadav 2020). Besides Fe, Zn is the most abundant metal in living organisms, is the only metal found in all enzyme classes, and has a role in nucleic acid, lipid, protein, auxin synthesis, and chlorophyll reactions. All these show how important it is as a micronutrient. The main cause of $\mathrm{Zn}$ deficiency is that $\mathrm{Zn}$ available in the soil is not suitable for plant uptake. Therefore, microbial biofortification is suggested as a strategy that can be used to eliminate $\mathrm{Zn}$ deficiency (Dotaniya et al. 2016).
Mycorrhiza inoculation is seen as an alternative option to increase productivity without polluting soil and water and disturbing the ecological balance. In addition, the chance of success increases when mycorrhiza-inoculated soil, plant, seed, etc. are used. The use of arbuscular mycorrhizal fungi (AMF), generally known as a biofertilizer, in breeding studies is increasing all over the world. The microorganisms in the soil and the plants share a symbiotic life. The use of AMF in agricultural crops aims to meet the micronutrient needs economically, use water, and protect the soil (Palta et al. 2010). AMF provides root development and ensures the uptake of nutrients such as phosphorus $(\mathrm{P})$, nitrogen $(\mathrm{N}), \mathrm{Ca}$, copper $(\mathrm{Cu})$, manganese $(\mathrm{Mn})$, sulfur $(\mathrm{S}), \mathrm{Fe}$, and $\mathrm{Zn}$. Gashgari et al. (2020) reported that the inoculation of AMF (Rhizophagus irregularis) in medicinal plants such as Mentha pulegium and Petroselinum hortense increases the biomass of plants and primary metabolites such as sugar, amino acids, fatty acids, secondary metabolites such as polyphenols, and minerals such as $\mathrm{Ca}, \mathrm{K}, \mathrm{Mg}, \mathrm{P}, \mathrm{Na}, \mathrm{Fe}$, $\mathrm{Cu}, \mathrm{Mn}$, and $\mathrm{Zn}$, and suggested that AMF is a promising approach that can be used in the food and pharmaceutical industry. The use of AMF for growing nutrient-rich crops is considered to be a more economical strategy than costly chemical fertilizers for Himalayan communities that suffer from hidden hunger due to $\mathrm{Fe}$ and $\mathrm{Zn}$ deficiencies (Kumar et al. 2016). It was reported that Pseudomonas spp. and Pseudomonas chlororaphis isolated from corn promote $\mathrm{Fe}$ uptake and germination, plant growth, and crop production (Sharma et al. 2003). Some microorganisms secrete Fechelating compounds called siderophores that facilitate the uptake of microelements such as $\mathrm{Fe}$. $\mathrm{Fe}^{3+}$ ions have very low solubility at neutral $\mathrm{pH}$ and thus cannot be used by organisms; however, siderophores facilitate Fe uptake by plants under different $\mathrm{pH}$ conditions.

\subsection{Genomic Approaches}

Applications of micronutrients to soil or to the leaves by surface spraying increase micronutrient concentrations in the edible parts of plants such as fruits, seeds, and bulbs; however, factors such as the accumulation of micronutrients in the non-edible parts of the plants such as leaves, limited mobility of some micronutrients, and differences in soil composition of geographies limit the accumulation of micronutrients in crops (Cakmak 2008; Cakmak et al. 2010a; Kalra et al. 2020). Increasing the micronutrient content of crops by agronomic methods is a short-term solution, and these fertilizers are also quite expensive for farmers in low-income countries. Since the excessive use of highcost inorganic fertilizers in agriculture reduces biodiversity, increases the proliferation of algae, and causes air and water pollution (at this point, the interest in biofertilizers has increased) (Jewell et al. 2020), plant breeding is accepted 
as a more sustainable strategy (Bouis and Saltzman 2017). However, this method depends on the diversity in the genetic pool of the targeted crop. Lack of genetic diversity and low heritability prevent biofortification with traditional breeding (Marques et al. 2021). Another disadvantage is that it requires a long-term comprehensive selection to introduce the function into a specific culture. In order to overcome such obstacles, various alternative applications are being developed.

Identification of genes controlling biofortification traits in cereals is seen as one of the strategies that can help reduce global micronutrient deficiencies by increasing the concentrations of micronutrients. The improvement of crops by genetic improvement for micronutrient content in crops is considered a more effective approach. Thus, genomic approaches such as marker-assisted selection (MAS) and quantitative trait loci (QTL) mapping and genomic selection (GS) are seen as cost-effective approaches for selecting desired plants and have been widely used for the biofortification of wheat.

Considering the example of wheat biofortification, advances in genomics have accelerated the improvement of several agriculturally important crops. However, being polyploid and having a large genome are compelling factors in wheat breeding. Thus, without a genome sequence, it has been difficult to design molecular markers and map loci that regulate the desired trait (Ali and Borrill 2020). A wheat landrace Chinese Spring genome sequence (RefSeqv1.0) representing 94\% of the whole wheat genome was published in 2018, and the high contiguity of this genome assembly was reported to be effective in genetic mapping of loci involved in $\mathrm{Fe}$ and $\mathrm{Zn}$ accumulation (Appels et al. 2018). The analysis of gene families related to biofortification and the interpretation of loci identified by QTL and genome-wide association study (GWAS) will be helpful. For example, wheat natural resistance-associated macrophage proteins (NRAMPs) were identified using phylogenetic trees from rice orthologs. However, it was also stated that RefSeqv1.1 gene annotations are not perfect due to the missing two of the 24 NRAMP genes (Ali and Borrill 2020). Such limitations are being developed with ongoing studies. On the other hand, the rice OSIRT1 gene (LOC_OsO3g46470) has an important role in Fe uptake (Lee and An 2009). The OsIRT1 promoter and/or its coding sequence were used in multi-biofortification studies in rice (Bonneau et al. 2018) and three orthologous TaIRT1 genes with conserved gene structure were found in the wheat genome on chromosome group 4 . It has been determined that these genes encode protein sequences with $73.0-74.2 \%$ identity with $O S I R T$.

MAS determines whether the plant carries the genomic regions required for the expression of a trait and whether it has the target trait (Lema 2018). Identifying quantitative trait loci (QTL) requires statistical methods, high-resolution genetic maps, and a large number of molecular markers. A good understanding of the genetic basis of micronutrients at the molecular level and identification of the important effects of QTLs help in the production of biofortified varieties through marker-assisted breeding. For example, more than 80 QTLs have been identified and mapped on 12 chromosomes for $\mathrm{Zn}$ and Fe content in rice. These identified QTLs and candidate genes can significantly enhance the efficacy of breeding programs to improve the $\mathrm{Zn}$ and $\mathrm{Fe}$ content in rice (Sharma et al. 2019). For the Mn concentration of the cereals, several QTLs were mapped on the 3, 7, and 8 chromosomes of the rice (Liu et al. 2017). Rice chromosome 3 is evolutionarily conserved across the cultivated cereals and shares large blocks of synteny with maize and sorghum (Minx et al. 2005). More than 133 agronomic genes/traits per QTL were found to be associated with chromosome 3 (Wu et al. 2002). The regions on chromosome 7 are related to the plant shoot and root development (Uddin and Fukuta 2020). Chromosome 8 has been reported to be effective in yield-related traits such as grain length and weight (Kang et al. 2018). In this study, one major QTL region was determined and the LOC_Os07g15370 (OsNRAMP5) gene was identified as the possible gene causing the high amount of $\mathrm{Mn}$ accumulation in rice grain (Liu et al. 2017). In a study conducted in wheat, a total of 16 QTLs were identified that contributed to the Se content at the seedling stage (Wang et al. 2017). MAS is an indirect selection process in which the desired trait is selected with DNA (such as intersimple sequence repeat (ISSR), simple sequence repeat (SSR), random amplified polymorphic DNA, and single nucleotide polymorphisms (SNPs)) and RNA markers known as molecular markers or specific markers such as morphological and biochemical. It is a technique that is routinely used in conventional breeding programs and facilitates the breeding and selection of suitable genotypes (Vlcko and Ohnoutkova 2019). This genomic approach has been used in the development of provitamin A in maize cultivars where germplasm with high $\beta$-carotenoid content was selected (Masuka et al. 2017). MAS provides high success in the development of nutrient-rich maize grain. As a result of MAS studies, provitamin A content increased from 1.60 to $5.25 \mu \mathrm{g} / \mathrm{g}$ and from 1.80 to $8.14 \mu \mathrm{g} / \mathrm{g}$ (Goredema-Matongera et al. 2021). In strategies such as genomic selection, QTL mapping, SNPs are used to identify genomic regions that affect nutritional characteristics. For example, more than 20 SNPs have been identified that have a direct effect on the accumulation of $\mathrm{Zn}$ content in maize (Hindu et al. 2018). 


\subsection{Micronutrient Biofortification Using Transgenic Approaches}

\subsubsection{Advantages and Disadvantages of Transgenic Approaches}

Increasing micronutrients in plants by genetic engineering is shown as a sustainable and cost-effective alternative to traditional fortification programs (Dunwell 2014; Kumar et al. 2019; Van Der Straeten et al. 2020). The aim of traditional breeding and genetic engineering, using for biofortification, is to manipulate the gene sequence of plants to accumulate micronutrients in the edible parts of plants and increase their bioavailability and plant diversity for human consumption (Kaur et al. 2020). In transgenic approach, new cultivars with desired traits can be developed by transferring new genes or overexpressing of the genes already present, or by blocking genes that provide inhibitor synthesis (Malik and Maqbool 2020). On the other hand, conventional breeding is insufficient for a particular crop/micronutrient combination. Nutritional-related genes from multiple parents can be combined into a single genotype by conventional backcross, but this method is very time consuming and laborious. Also, it is quite difficult to combine more than one trait with the traditional method, given the difficulty of simultaneous selection of multiple traits (Van Der Straeten et al. 2020). Today's transgenic technologies save time in the design and development of a multi-nutrient product. The genetic engineering allows the simultaneous addition of multiple micronutrients (multi-fortification) in a single product and can increase the amount and accumulation of multiple micronutrients in products (Van Der Straeten et al. 2020). In this way, many new traits are transferred to a crop more quickly. For example, a simultaneous increase in $\mathrm{Fe}, \mathrm{Zn}$, and $\beta$-carotene content was achieved in polished rice (Singh et al. 2017).

There are no evolutionary and taxonomic restrictions in genetic engineering (Garg et al. 2018), and synthetic genes can be designed and used (Hirschi 2009). That is, using various genes from different sources, many crops rich in nutrients such as vitamins, minerals, amino acids, and fatty acids can be developed. With this, well-defined gene or genes are transferred by genetic engineering; there is no risk of transferring untargeted genes to the products to be developed (CAST 2020).

Genetic biofortification aims to increase the uptake and transport of micronutrients to the shoots by genetic engineering, increase of density of micronutrients to edible portions of the cereal grains such as endosperm, and reduce the anti-nutrient factors. It can be used to develop higher quality crops in terms of more bioavailability by increasing the mineral and vitamin levels in the starchy endosperm of cereal seeds. Conventional breeding cannot develop rice enriched with vitamin $\mathrm{A}$, but it has been achieved by genetic engineering (Ye et al. 2000). In this study, biosynthesis of provitamin A in endosperm was achieved with a combination of transgenes using recombinant DNA technology (Ye et al. 2000).

The phytic acid, which is the main storage form of phosphorus, is a food inhibitor that chelates micronutrients and prevents bioavailability (Gupta et al. 2015). In other words, phytic acid acts as an anti-nutritional agent by blocking the absorption of minerals such as $\mathrm{Fe}, \mathrm{Zn}$, and $\mathrm{Ca}$ (Akond et al. 2011; Feil 2001). The transgenic method can be used to reduce the phytic acid content in foods and to help alleviate malnutrition by improving the nutritional value of the grain which becomes poor due to such anti-nutrients. In addition, transgenic technology can also be used to simultaneous incorporation of genes involved in increasing the micronutrient concentration and reducing the concentration of anti-nutrients that reduce the bioavailability of nutrients (Garg et al. 2018).

On the other hand, for the plant development strategy with the transgenic approach, it is necessary to have sufficient basic knowledge about the micronutrient metabolism of the plant, so it may require a higher entry cost than traditional methods (Strobbe et al. 2018). In addition, the potential discovery of new genes involved in micronutrient metabolism is less likely than with conventional methods (CAST 2020).

Although genetic biofortification is a potential strategy to combat malnutrition, a skeptical approach to gene technologies is seen as an important obstacle for the development of genetically modified plants, especially in European Union countries. This technology is under strict control in many countries.

\subsubsection{Transgenic Approaches for İmprovement of $\mathrm{Zn}$ and Fe Content in Plants}

Many crops have been successfully modified using the transgenic approach to overcome the micronutrient deficiency. The single or multiple gene overexpressions were used to modulate biochemical pathways such as transport of micronutrient. Studies showed that $\mathrm{Zn}$ accumulation occurs in plants with the overexpression of the transporters such as transmembrane transporters in the ZIP (ZRT and IRT-like protein) family and has an important role in the acquisition of $\mathrm{Zn}^{+2}$ from the root-soil interface. It is also known that nicotianamine synthase (NAS) genes are expressed in the $\mathrm{Zn}^{2+}$ deficiency and that $\mathrm{Zn}$ plays a role in intercellular and long-distance transport (Cardini et al. 2021). The ZIP member IRT1 is also a major root Fe transporter. The IRT2 gene, a close homologue of $I R T 1$, encodes a high-affinity $\mathrm{Fe}$ transporter. Studies have shown that expression of both IRTI and IRT2 genes is induced in the root upon Fe starvation (Vert et al. 2001; Wairich et al. 2019). Different methods 
are used to increase Fe uptake and content in cereals, such as the modulation of the expression of ferritin, the Fe storage protein, to increase the Fe storage capacity, regulation of metal homeostasis for its transport to shoots and seeds, and increasing the synthesis of metal chelators. Wirth et al. (2009) reported that when compared to wild type, the amount of $\mathrm{Fe}$ and $\mathrm{Zn}$ in rice increased significantly with the co-expression of Arabidopsis synthase, bean ferritin, and Aspergillus phytase and overexpression of ferritin protein in rice and soybean. In another study, it was determined that $\mathrm{Fe}$ concentration increased up to 70 times compared to non-transgenic control groups as a result of overexpression of Arabidopsis vacuole Fe transporter (VITI) in transgenic cassava plant (Narayanan et al. 2019). Carrier proteins can usually carry more than one metal. It was determined that both $\mathrm{Fe}$ and $\mathrm{Zn}$ accumulation increased in transgenic rice engineered as a result of induction of overexpression of genes encoding $\mathrm{Fe}$ regulator-carrier-like protein 1 (Lee et al. 2009). Increasing the synthesis of metal chelators such as nicotianamine (NA) and mugineic acids (MAs) increases $\mathrm{Fe}$ and $\mathrm{Zn}$ accumulation in the edible parts of the plants (Slamet-Loedin et al. 2015). Fe accumulation increases in the seed and endosperm with the expression of genes encoding ferritin and genes encoding some carrier proteins such as vacuolar Fe transporter 1 (VITl) responsible for Fe, $\mathrm{Zn}$, and Mn homeostasis (Bashir et al. 2016; Briat et al. 2010). Therefore, transgenic cereals fortified in $\mathrm{Fe}$ and $\mathrm{Zn}$ are also produced by the modulation of genes that control $\mathrm{Fe}$ and $\mathrm{Zn}$ homeostasis and regulate bioavailability. However, genetic modulations in the expression of genes encoding transporters affect $\mathrm{Cd}$ and $\mathrm{Zn}$ concentrations. $\mathrm{P}, \mathrm{Zn}$, and $\mathrm{Fe}$ are acquired in the form of free ions around the root in plants and the uptake and transport of these minerals in plants involve multiple and complex transport systems (Nussaume et al. 2011). Due to the chemical similarity between $\mathrm{Cd}$ and Zn, Zn-regulatory transporter (ZRT), Fe-regulating transporter-like (IRT-like) protein (ZIP), and heavy metal ATPases (HMAs) also serve as Cd transporters (Cun et al. 2014; Takahashi et al. 2012; Uraguchi and Fujiwara 2012). Detterbeck et al. (2016) conducted a study on barley and determined that high $\mathrm{Zn}$ concentration is associated with high $\mathrm{Cd}$ content. For this reason, genetic biofortification with transgenic methods may be risky for $\mathrm{Cd}$ accumulation (Cakmak and Kutman 2018). Moreover, the expression of ferric chelate reductase, which has a role in Fe uptake, and Fe-regulated transporter 1 (IRT1), which is the main transporter for Fe absorption from the soil, is regulated by phytohormones such as auxin, cytokinin, ethylene, and jasmonic acid (Hindt and Guerinot 2012; Kobayashi and Nishizawa 2012). Studies using ethylene and ethylene precursors showed that ethylene regulates the expression of Fe uptake genes (García et al. 2015; Ye et al. 2015). Omic approaches such as reverse transcription PCR (RT-PCR) and microarray evidenced that genes regulating Fe deficiency are sensitive to ethylene (García et al. 2010; Mai et al. 2016).

Plants try to maintain $\mathrm{Zn}$ levels by the mechanisms of $\mathrm{Zn}$ homeostasis such as $\mathrm{Zn}$ uptake, transport, and storage. In a recent study, it was tried to determine how plants meet this $\mathrm{Zn}$ condition. It was found that bZIP19 and bZIP23 (Assunção et al. 2010), which are the Zn-deficient Arabidopsis thaliana F-group bZIP transcription factors and bind to $\mathrm{Zn}$ deficiency response elements (ZDRE) in the promoter regions of target genes required for $\mathrm{Zn}$ uptake, transport, and distribution in $\mathrm{Zn}$-deficiency, act as a $\mathrm{Zn}$ sensor and bind to $\mathrm{Zn}^{+2}$ ions to a $\mathrm{Zn}$ sensor motif (ZSM): Cys/His-rich motifs (Lilay et al. 2020). This ZSM deletion or modification prevents $\mathrm{Zn}$ to bind, leading to a constitutive transcriptional $\mathrm{Zn}$ deficiency response that results in increased $\mathrm{Zn}$ accumulation in the plant and seed (Lilay et al. 2020). ZSM is highly conserved in land plants; therefore, the identification of these sensors will contribute to the development of new strategies for eliminating $\mathrm{Zn}$ deficiency in crops, increasing yield and quality, and combating global malnutrition due to Zn deficiency. The Gpc-Bl (Grain protein content-B1) gene taken from wild emmer wheat regulates the protein content as well as the content of micronutrients such as $\mathrm{Fe}$ and $\mathrm{Zn}$ in the grain. The most important characteristic of this gene is that it encodes the NAM-B1 transcription factor, which mobilizes the macroelement $\mathrm{N}$ and the microelements $\mathrm{Fe}$ and $\mathrm{Zn}$. Wild emmer wheat has three genes encoding this transcription factor. However, modern bread wheat varieties have lower amounts of protein, $\mathrm{Zn}$, and $\mathrm{Fe}$ as they contain a dysfunctional allele gene. Therefore, it is aimed to use the $G p c-B 1$ gene in obtaining productive wheat cultivars (Cakmak 2008). In another study, recombinant human lactoferrin $(\mathrm{r} H L F)$ gene was expressed in rice considering that HLF proteins in breast milk may increase Fe uptake due to their high affinity for $\mathrm{Fe}$ and it was determined that both HLF protein and $\mathrm{Fe}$ amounts increased in cereal grains (Lönnerdal and Bryant 2006). Many studies have been carried out for the transport of micronutrients in crops and to increase their content (Table 1).

\subsubsection{Crop Biofortification for Vitamins with Transgenic Approaches}

One of the aims of biofortification is to increase vitamin levels in fortified foods, as well as to reduce or prevent the deterioration of these vitamins after harvest and during long storage. There are different approaches to increase the level of $\beta$-carotene in processed basic products. Inducing chromoplast formation and increasing the $\beta$-carotene level by transferring the orange (Or) gene to potatoes ( $\mathrm{Li}$ et al. 2012), increasing the level of $\beta$-carotene in polished rice with the 
Table 1 Transgenic biofortified crops with enhanced micronutrients

\begin{tabular}{|c|c|c|c|}
\hline Crops/Cultivar & Nutrient & Gene & Reference \\
\hline Oryza sativa & $\mathrm{Zn}$ and $\mathrm{Mn}$ & TaCNR5 & Qiao et al. (2019) \\
\hline Oryza sativa L. (cv. EYI105) & $\mathrm{Fe}$ and $\mathrm{Zn}$ & $O s N A S_{1}$ & Diaz-Benito et al. (2018) \\
\hline Oryza sativa & $\mathrm{Fe}$ & OsYSL13 & Zhang et al. (2018a) \\
\hline Oryza sativa & $\mathrm{Cu}$ & OsYSL16 & Zhang et al. (2018b) \\
\hline Indica rice $\mathrm{cv}$. IR64 & $\mathrm{Fe}$ and $\mathrm{Zn}$ & AtNRAMP3, AtNAS1, PvFER & Wu et al. (2018) \\
\hline Oryza sativa & $\mathrm{Fe}$ & OsDMAS1 & Bashir et al. (2017) \\
\hline Oryza sativa & $\mathrm{Fe}$ & OsYSL9 & Senoura et al. (2017) \\
\hline Oryza sativa & $\mathrm{Fe}$ & OsFRDL1 & Yokosho et al.(2016) \\
\hline Indica Rice & $\mathrm{Fe}$ and $\mathrm{Zn}$ & $\mathrm{OsNAS}_{2}$, sferH-1 & Trijatmiko et al. (2016) \\
\hline Oryza sativa L. cv. japonica & $\mathrm{Fe}$ and $\mathrm{Zn}$ & $M x I R T_{1}$ & Tan et al. (2015) \\
\hline Oryza sativa L. cv. japonica & High Zn & OsPCRl & Song et al. (2015) \\
\hline Oryza sativa $\mathrm{L}$. & Vitamin B9 & GTPCHI, ADCS & Dong et al. (2014) \\
\hline Triticum aestivum $L$. & $\mathrm{Fe}$ & $O s N A S_{2}$ & Beasley et al. (2019) \\
\hline Triticum aestivum and Zea mays & Vitamin B9 & Gm8gGCHI, GmADCS, LeADCS & Liang et al. (2019) \\
\hline Triticum aestivum $L$. & $\mathrm{Fe}, \mathrm{Zn}, \beta$-carotene & $O s N A S_{2}$ & Singh et al. (2017) \\
\hline Triticum aestivum $L$. & $\mathrm{Fe}$ and $\mathrm{Mn}$ & TaVIT2 & Connorton et al. (2017) \\
\hline Triticum turgidum and Triticum aestivum & $\beta$-carotene & $C C D s$ & Qin et al. (2016) \\
\hline Triticum aestivum $L$. & Provitamin A & CtrB, ctrl & Wang et al. (2014) \\
\hline Hordeum vulgare & $\mathrm{Zn}$ & Hvzip7 & Tiong et al. (2014) \\
\hline Zea mays & $\alpha$-tocopherol & $Z m T M T$ & Zhang et al. (2020) \\
\hline Maize & $\alpha$-tocopherol & GmTMT2af & Zhang et al. (2013) \\
\hline Glycine $\max$ & $\beta$-carotene & $\begin{array}{l}\text { PSY, phytoene desaturese, lycopene } \\
\quad \beta \text {-cyclase }\end{array}$ & Schmidt et al. (2015) \\
\hline Indian soybean & $\gamma$-tocopherol & $\gamma-T M T$ & Arun et al. (2014) \\
\hline Glycine $\max ($ L.) Merrill & $\mathrm{Fe}$ & $H v N A S 1$ & Nozoye et al. (2014) \\
\hline Glycine max L. cv. Kwangan & $\beta$-carotene & PYS, carotene desuturase & Kim et al. (2012) \\
\hline Solanum lycopersicum $L$. & Iodine & $H M T, S 3 H, S A M T$ & Halka et al. (2019) \\
\hline Solanum lycopersicum $L$. & Ascorbate & GMPase, ALO, MIOX2 & Cronje et al. (2012) \\
\hline Solanum lycopersicum & Ascorbate & SlGMEs & Zhang et al. (2011) \\
\hline Solanum tuberosum $L$. & Vitamin B6 & $P D X-I I$ & Bagri et al. (2018) \\
\hline Sweet potato (cv. White Star) & $\mathrm{Fe}$ & $H v N A S 1$ & Nozoye et al. (2017) \\
\hline Solanum tuberosum $L$ & $\beta$-carotene & $S t L C Y b$ & Song et al. (2016) \\
\hline Manihot esculenta Crantz & $\mathrm{Fe}$ and $\mathrm{Zn}$ & VIT1, IRT1, FER1 & Narayanan et al. (2019) \\
\hline Manihot esculenta Crantz & Vitamin B6 & $A t P D X 1.1, A t P D X 2$ & Li et al. (2015) \\
\hline Sorghum bicolor & Vitamin E, $\beta$-carotene & Psyl, crt1, At-dxs, pmi, hggt & Che et al. (2016) \\
\hline Arachis hypogaea $L$. & $\mathrm{Fe}$ and $\mathrm{Mn}$ & $A n N R A M P_{1}$ & Wang et al. (2019) \\
\hline
\end{tabular}

Or gene (Bai et al. 2016), suppressing the degradation of provitamin $A$ to increase the $\beta$-carotene levels in wheat (Zeng et al. 2015), can be given as examples.

Considering the long post-harvest storage period, it is of great importance to ensure storage stability for vitamins. Long-term stabilization of vitamin B9 was achieved by transferring genes that ensure the expression of folate binding proteins (aminodeoxychorismate synthase and GTP cyclohydrolase I). In polished rice, folate accumulation was increased up to 150 times compared to wild-type rice levels, and it was suggested that this approach may also be effective in increasing the stability of vitamins B1 and B6 (Blancquaert et al. 2015).

Gene transfer can be used to improve crops with multiple micronutrient deficiencies. Sorghum grain is a very low plant in terms of provitamin A, Fe, and Zn bioavailability. It was determined that the transfer of the homogentisate geranylgeranyl transferase $(h g g t)$ gene, which is required for vitamin E synthesis, to sorghum plant causes an increase in the amounts of major vitamin E (tocochromanols, $\alpha$-tocotrienol, $\alpha$-tocopherol, $\gamma$-tocopherol) as well as all-trans $\beta$-carotene (lutein, zeathanthin, $\alpha$-carotene, 13 -cis $\beta$-carotene, and 9-cis $\beta$-carotene) (Che et al. 2016) (Table 1). Researchers reported 
that this approach is promising for people suffering from vitamin A deficiency by increasing the amount and stability of provitamin A in many food products.

Different simulation studies confirmed that consumption of biologically fortified crops positively affects human nutrition and that regular consumption of these fortified crops can reduce micronutrient deficiencies (De Steur et al. 2017). For example, simulation analysis of Golden Rice which was biologically fortified for provitamin A in Asia showed that vitamin A deficiency can be reduced (de Moura et al. 2016).

\subsubsection{Future Perspectives}

An efficient biofortification can be achieved by increasing both the concentrations of micronutrients and the bioavailability of micronutrients. The identification of many of the key genes involved in micronutrient uptake, translocation, and storage will facilitate the development of crops (other target micronutrients) enriched by transgenic approaches. Some traits (such as provitamin A in rice seed) that cannot be obtained by plant breeding can be introduced by the transgenic method (CAST 2020).

To help overcome micronutrient deficiencies in developing countries, pulse crops biofortified using conventional plant breeding approaches have been released by HarvestPlus (Jha and Warkentin 2020). However, it has been reported that there are no examples of pulse crop improvement by transgenic biofortification for Fe, $\mathrm{Zn}$, Se, I, carotenoids, or folate (Jha and Warkentin 2020). Previous transgenic studies have found positive results in these plants, at least for other nutrients such as amino acids. The expression of the Brazil methionine-rich storage albumin gene caused an increase in the amount of methionine amino acid by $23 \%$ in the transgenic bean plant (Aragão et al. 1999). In a similar study, it was determined that the sunflower seed albumin gene caused a $94 \%$ increase in methionine concentration in transgenic lupine plants (Molvig et al. 1997). Therefore, these findings open the door to the use of gene editing (see 3.5.) and transgenic technologies in the development of pulse cultivars with desired traits. Sub-Saharan Africa is one of the regions where $\mathrm{Zn}$ deficiency is most prevalent and beans are consumed the most (Philipo et al. 2021), so genetically enriching the common bean with zinc will have a high impact on reducing zinc deficiency.

Transgenic biofortification is certainly not an approach that alone can solve the problem of malnutrition. However, it can be used as a complementary option in reducing the burden of malnutrition. As efforts to block transgenic crops continue, hidden hunger from micronutrient deficiency, a major public health problem, continues to affect poorer populations the most. It is necessary to make arrangements to reduce the negative perception of the society towards transgenic foods and to remove restrictions such as intellectual property that prevent the delivery of biologically enriched foods to the poor.

\subsection{Genome Editing Technology}

There are different approaches regarding the regulatory effect of the palindromic repeat clusters (CRISPR/Cas) system used in genome editing, which is a genetic engineering technique with the 2020 Nobel Chemistry prize and allows cleaving and recombining DNA strands.

The meganucleases, such as Zn-finger nucleases (ZFNs) and transcription activator-like effector nucleases (TALENs), used in changing the targeted region in any genomes for genome editing (GE) have great potential for crop improvement. These meganucleases have been used to genetically modify plants such as tobacco, Arabidopsis, rice, wheat, and barley (Ansari et al. 2020; Jaganathan et al. 2018; Sedeek et al. 2019). ZFN and TALEN are not preferred much because they are costly as compared to CRISPR/Cas, and have limited efficiency and are time consuming and difficult to design these proteins (Shiva Krishna and Suma 2019). Another alternative way to manipulate gene function is the use of mutagenized populations. It is seen as a more effective and easier approach than traditional TILLING (Targeting Induced Local Lesions IN Genomes) approaches, where it is very difficult to find a mutation in a related gene (Ali and Borrill 2020). CRISPR-Cas9 is a two-component system consisting of guide RNA that recognizes the target sequence in the genome and CRISPR-associated endonuclease (Cas) that cuts the targeted sequence. It provides precise editing of any sequence in the genome. Since RNA synthesis is easier and cheaper, it makes the CRISPR/Cas system more advantageous than ZFN and TALEN approaches (Aglawe et al. 2018). In order to determine the effect of OsZIP9 gene, which is a member of Zn-IRT-related proteins and is involved in $\mathrm{Zn}$ uptake, on $\mathrm{Zn}$ accumulation, OsZIP9 was knocked out by the CRISPR/Cas 9 system and mutant rice plants were grown in a hydroponic solution with low $\mathrm{Zn}$ concentration. Compared to the wild type, Zn content decreased in roots and shoots of knockout lines. This study reported that OsZIP9 functions as a flux carrier of $\mathrm{Zn}$ and increases $\mathrm{Zn}$ uptake in rice under $\mathrm{Zn}$-limited conditions (Huang et al. 2020). The CRISPR/Cas9 system was used in rice in order to prevent excessive accumulation of micronutrients with toxic properties such as $\mathrm{Cd}$. The metal transporter gene, $O s N$ ramp5, was deactivated in the rice plant, $\mathrm{Cd}$ accumulation in the shoots and roots of the osnramp5 mutants decreased, and this was found to have a positive effect on growth (Tang et al. 2017). On the other hand, Ishimaru et al. (2012) and Takahashi et al. (2014) found that more $\mathrm{Cd}$ accumulated in 
OsNramp5 mutants compared to wild type. Therefore, it was stated that it is unlikely that these different results are due to the role of OsNramp5 directly. There is strong evidence that $\mathrm{Cd}$ and $\mathrm{Fe}$ share transporters such as OsIRT1, OsIRT2, OsNramp1, and OsNramp5 in rice (Sasaki et al. 2012; Senoura et al. 2011). Expression of these $\mathrm{Fe} / \mathrm{Cd}$ transporter genes was found to be highly induced in OsNramp5 knockout or knockout lines, especially in the case of Fe deficiency (Takahashi et al. 2014; Yang et al. 2014). It has been reported that the reason for the difference in $\mathrm{Cd}$ accumulations may be due to the different degrees of suppression of the expression of OsNramp 5 in the rice lines, as well as the induction of other Fe/Cd transporters (Sasaki et al. 2012; Takahashi et al. 2014).

Fortification of crops with $\beta$-carotene (provitamin A) is suggested as a potential strategy to solve the problem of vitamin A deficiency, which is common in developing countries (Endo et al. 2019). In a recent study, $\beta$-carotene was rapidly accumulated in rice calluses with the modification of the Orange (or) gene, which causes the accumulation of $\beta$-carotene in cauliflower by genome editing using CRISPR/ Cas9 (Endo et al. 2019). In another study, rice with high carotenoid content was developed by adding a carotenoid biosynthesis cassette with the CRISPR-Cas9-based method (Dong et al. 2020).

CRISPR-Cas9 is seen as a promising strategy in producing more durable and tolerant crops by stimulating the development of multi-resistance to many abiotic and biotic stress factors in non-transgenic but modified by genome-edited plants and in reducing global food scarcity by improving crop quality and yield (Vestergaard et al. 2014). However, off-target effects such as cleaving the wrong genes, altering the function of genes, or genomic instability are among the important disadvantages of this system. CRISPR-Cas9 application can also cause great harm by producing off-target mutations (Naeem et al. 2020). The problem is that large genomes contain identical or substantially similar homologous regions. CRISPR-Cas9 can target these similar regions instead of the region it should cut. Targeting these undesirable regions can create mutations that cause cell death or transformation. However, several strategies have been developed to reduce off-target effects or limitations in CRISPRmediated genome editing. Various techniques have been reported for the detection of off-target mutations, including in silico detection and different bioinformatics approaches. Off-target detection methods are categorized into two groups, biased tools (to detect and evaluate guide RNA (gRNA) efficiency) and unbiased tools (detects unwanted cleavage sites in living cells at the whole genomic level). The most preferred off-target detection biased and unbiased methods are Elevation (Listgarten et al. 2018) and GUIDEseq (Tsai et al. 2015). In addition, it is crucial to select Cas variants to reduce off-target effects. For this purpose, studies are underway to develop engineered Cas9 variants with negligible off-target effects and new gene targeting techniques (Naeem et al. 2020). The United States Department of Agriculture has exempted the application of GMO regulations on many crops modified by the CRISPR system whereas the Court of Justice of the European Union has declared that strict GMO regulations will be applied (Callaway 2018). In all these genomic studies, another critical question, besides the legal regulations, is whether these food crops developed with different genomic editing tools will be accepted by the public.

\subsection{Biofortification Through Nanoencapsulation}

The crop yield is tried to be increased by co-applying micronutrients and N, P, and K (NPK) fertilizers to soils that are deficient in micronutrients in order to meet the nutritional needs of billions of people in the world. The common point with micronutrients in diverse global agricultural ecosystems is that crop deficiencies increase with the low efficiency of crop use. Micronutrient use efficiency (MUE) is defined as the biomass yield per unit input of fertilizer and nutrient content (Meena et al. 2014). It was also reported that the interactions between micronutrients and macronutrients can affect crop yield positively or negatively. In other words, the interaction of fertilizer-micronutrients with macronutrients can occur as a synergistic, antagonistic, or neutral reaction that may affect the yield and quality of the product. It was determined that high amounts of $\mathrm{P}$ applied to the soil cause $\mathrm{Cu}$ deficiency in plants such as corn, beans, citrus, and tomato. It was reported that NPK fertilization for rice and wheat cultivation in India increases the crop yield whereas the bioavailability of micronutrients such as $\mathrm{Zn}$ becomes so limited, and as a result, it poses a big problem in $\mathrm{Zn}$ nutrition for humans (Cakmak 2009; Monreal et al. 2015). Despite the increase in crop yield with NPK fertilization, reasons such as the lack of increase in crop yield in regions with less favorable biophysical conditions and hidden hunger in people consuming products with low micronutrient values necessitate sustainable new solutions to produce crops with high crop yield and nutrient quality.

Today, increasing crop yield, food nutrition, and fertilizer-micronutrient use efficiency around the world have required the use of nanotechnology and biotechnological methods (Akhter et al. 2013; De Rosa et al. 2010). New strategies such as nanoencapsulation and microencapsulation, nanomaterials, nanodevices, and nanoparticles are among the methods that aim to increase the micronutrient use efficiency (Monreal et al. 2015). Nanoencapsulation is the technology of encapsulating micronutrients in different materials and coating in nanosizes. Nanocapsules are in the submicron range and function as a vehicle for encapsulating with nanometric films, layers, and coating materials and 
transporting the component to the desired site of action. Microencapsulation is the process of coating or packaging small solid, liquid, or gas particles, which constitute the active core, with another thin polymeric secondary material called encapsulant (Gharsallaoui et al. 2007). Microcapsulemicron size ranges between 1 and $1000 \mu \mathrm{m}$ (Bratovcic and Suljagic 2019). In nanoencapsulation, mesoporous aluminosilicates, which contain a mixture of silica and $\mathrm{Al}$ and active sites for ion exchange and adsorption, are used as $\mathrm{CuO}$ nanoparticle carriers in the controlled release of macro- and microelements into the soil (Huo et al. 2014). Crop yield and micronutrient concentration are increased by ensuring the uptake of microcapsules, nanocapsules, nanomaterials, and nanoparticles such as $\mathrm{Zn}, \mathrm{Fe}, \mathrm{Mn}$, and $\mathrm{CuO}$, to which micronutrients are added, by plants. Encapsulation protects micronutrients from various environmental factors such as $\mathrm{pH}$, light, and oxidants. In addition, providing a controlled slow-release with the compounds used in the coating of these nutrients and increasing the solubility of less soluble compounds by encapsulation increase the bioavailability of micronutrients (Karunaratne et al. 2017). Studies on encapsulated micronutrients were mainly performed in the food and pharmaceutical industries. Different coating materials are used depending on the target molecule, cell tissue or organism, and environmental conditions. Polymers such as ethylene-vinyl acetate, gelatin, zein, alginate, chitosan, lignosulfate, pectin, and starch are used for micronutrient coating (Wang et al. 2013). Polymer films are used in microcapsules for the controlled release of commercial fertilizers into the soil solution. Cui et al. (2010) reported that coating the nutrients in water-soluble fertilizers with materials such as resin-polymer, wax, and sulfur will reduce the loss of nutrients in the fertilizer through permeation to the soil and increase the bioavailability of nutrients; thus, the rate of nutrient release can be controlled. Mn oxide nanoparticles accumulate on the root surface, taken into the plant, and then migrate. It was reported that nanostructures containing a core fortified with $\mathrm{Zn}$ and a shell around the core consisting of Mn carbonate increase the $\mathrm{Zn}$ use efficiency in rice by adding micronutrients to the roots of the plant. Nanoencapsulation of $\mathrm{Zn}$ using $\mathrm{Mn}$ increases grain yield while reducing nutrient loss (Yuvaraj and Subramanian 2014). In another study, it was determined that $\mathrm{ZnO}$ nanoparticles with an average size of $25 \mathrm{~nm}$ increase the yield and $\mathrm{Zn}$ amount in corn compared to $\mathrm{ZnSO}_{4}$ application and that $\mathrm{ZnO}$ nanoparticles can be effective in improving human health (Subbaiah et al. 2016). High water solubility, the ability of nanoparticles smaller than $100 \mathrm{~nm}$ to penetrate the plant quickly, having a large surface area that can interact with other molecules, non-toxicity, and the potential to minimize environmental pollution are the main reasons for the use of nanomaterials to increase micronutrient efficiency (Kalra et al. 2020). It was previously mentioned that unlike the application to the soil, the application of microelements such as $\mathrm{Fe}, \mathrm{Mn}, \mathrm{Cu}$, and $\mathrm{Zn}$ as liquid fertilizers to the leaves by the surface spraying method is considered a more effective method in reducing the delay of nutrient uptake. If this foliar application method is used for nanofertilizers, it will provide a great agronomic efficiency since stoma (when the stoma is open) and leaf epidermal cells will be involved in nutrient uptake (Kalra et al. 2020). Some studies showed that nanofertilizers accelerate metabolism with the foliar application and enhance plant growth by supporting meristematic activity. For example, the dry weight of the mint plant increases with $\mathrm{N}$ nanofertilization (Rostami et al. 2017), and carbohydrate and protein production in maize increases with Fe nanofertilization (Sharifi et al. 2016). Compared with other fertilizers used in agriculture, the use of nanofertilizers is considered to be a sustainable, low-cost method to increase soil fertility, product yield, and quality. However, overdoses of nanofertilizers can cause some problems at the soil-plant interface and it has been reported that it can cause toxic effects for plants, animals, microorganisms, and plants (Landa 2021).

On the other hand, nanoparticles were obtained by using of extracts and parts of the plant such as leaves, roots, flowers, and seeds; microbes such as bacteria, fungi, algae, and yeast; and biomolecules such as enzymes, proteins, and carbohydrates. This biogenic green synthesis of nanoparticles is more economical and environmentally friendly. Examples are the production of Fe-NPs from green tea and black tea leaves (Mareedu et al. 2021), ZnO-NPs from Nilgiriantusciliantus leaves (Resmi et al. 2021), and nickel oxide-NPs from fennel (Nigella sativa) seeds (Boudiaf et al. 2021). These green synthesized nanoparticles are successfully used as an antimicrobial agent, alternative energy source, and catalyst in human health-related issues (El Ramady et al. 2021). It has been reported that these nanonutrients such as nanoSe can support the fight against many diseases, especially COVID-19 (as anti-COVID-19 nanoparticles) (He et al. 2021).

\section{Conclusion}

Micronutrient deficiency is considered one of the most important problems threatening human health worldwide (WHO 2007). Most of the global population does not have access to fruits, vegetables, and animal products consisting of micronutrients and vitamins necessary for proper nutrition. However, the COVID-19 pandemic, which is currently a global health crisis, along with many diseases caused by micronutrient deficiencies, has highlighted the value of biofortified crops as a practical and cost-effective strategy for delivering essential micronutrients to billions of people. The concentration of minerals and vitamins in 
food staples, which are widely consumed by the poor population, can be increased by using different biofortification techniques. One of these strategies, the major advantage of traditional breeding programs, is that breeding biofortified food is more easily accepted by humans on a global scale compared to transgenically fortified food. Since this method is more sustainable and low cost, it draws more attention from poor farmers living in regions where micronutrient deficiencies are most common, such as Africa, Asia, and Latin America (FAO 2017). Although plant breeding and agronomic biofortification used in biofortification of crops are usually successful techniques, they are not considered sufficient to eliminate some micronutrient deficiencies. On the other hand, due to disadvantages such as lack of genetic diversity and low heritability, MAS is used as a complementary and supportive new strategy to increase the success of conventional breeding. However, the greatest risk of MAS is the narrowing of genetic diversity. Although transgenic biofortification, which aims to transport and distribute micronutrients between tissues, increasing their concentration in the edible parts of crops and the efficiency and productivity of biochemical pathways in their synthesis, requires time, effort, and investment at the beginning, it is seen as a more cost-effective and sustainable method in the long term. However, the time-consuming and high-cost legal regulations for the commercial distribution of developed food crops, the difficulties in obtaining approval from governments, the concerns and demands of anti-GMO activists for more testing before distribution, and the low public acceptance are the main disadvantages of this method. Despite these difficulties, traditional and marker-supported plant breeding, genetic applications, and various biofortification strategies based on both the agronomic and nanoencapsulation applications of micronutrients to the soil or surface have promising potential to improve health and the nutritional diets of people living in poor geographies suffering from micronutrient deficiencies.

It is an undeniable fact that the biggest threat to global human health today is the COVID-19 pandemic. The effects of this threat were more severe especially in poor countries due to malnutrition conditions. Worse still, COVID-19, climate change, and malnutrition have converged to make it an even more devastating threat to millions of people. The production of biologically fortified foods that will strengthen human immunity is seen as an approach that will help to overcome COVID-19 and similar pandemics. These biofortification strategies will help vulnerable people to be more resilient against income and food system shocks that may occur due to negative factors such as possible pandemics and natural disasters in the future. Therefore, governments should prevent discrimination against biofortified staple foods by promoting the widespread adoption of fortified staple cultivars and by providing official support. Let us not forget that the lessons to be learned and the global responses to be given from global crises such as COVID-19 and climate change will be an investment in the future of humanity.

Author Contribution Not applicable.

Data Availability Data will not be available for this review paper.

Code Availability Not applicable.

\section{Declarations}

Ethics Approval Not applicable.

Consent to Participate All authors have given their full consent in this collaboration.

Consent for Publication All authors have fully agreed and consented on the publication and submission of this manuscript in the Journal of Soil Science and Plant Nutrition under question.

Conflict of Interest The authors declare no competing interests.

\section{References}

Abbas A, Murtaza S, Asla F, Khawar A, Rafique S, Naheed S (2011) Effect of processing on nutritional value of rice (Oryza sativa). World J Med Sci 6:68-73

Abdalla M, Smith P (2016) Climate and soil functions: impacts on soil processes and properties and future implications in the UK-a review. Agric Forest Rep Card Paper 2. https://aura.abdn.ac.uk/ bitstream/handle/2164/8043/LWEC_technical_Paper.pdf?seque nce $=1$. Accessed 29 Sept 2021

Aglawe SB, Barbadikar KM, Mangrauthia SK, Madhav MS (2018) New breeding technique "genome editing" for crop improvement: applications, potentials and challenges. 3 Biotech 8:1-20. https:// doi.org/10.1007/s13205

Akhtar S, Das JK, Ismail T, Wahid M, Saeed W, Bhutta ZA (2021) Nutritional perspectives for the prevention and mitigation of COVID-19. Nutr Rev 79(3):289-300. https://doi.org/10.1093/ nutrit/nuaa063018-1355-3

Akhter S, Ahmad I, Ahmad MZ, Ramazani F, Singh A, Rahman Z, Ahmad FJ, Storm G, Kok RJ (2013) Nanomedicines as cancer therapeutics: current status. Curr Cancer Drug Targets 13:362378. https://doi.org/10.2174/1568009611313040002

Akond AGM, Heath Crawford JB, Talukder ZI, Hossain K (2011) Minerals ( $\mathrm{Zn}, \mathrm{Fe}, \mathrm{Ca}$ and $\mathrm{Mg}$ ) and antinutrient (phytic acid) constituents in common bean. Am J Food Technol 6:235. https://doi.org/ 10.3923/ajft.2011.235.243

Ali MW, Borrill P (2020) Applying genomic resources to accelerate wheat biofortification. Heredity 125:386-395. https://doi.org/10. 1038/s41437-020-0326-8

Allen L, Benouist B, Dary O, Hurrell R (2006) Guidelines on food fortification with micronutrients. World Health Organization, Food and Agricultural Organization of the United Nations, Geneva, p 376 
Alloway BJ (2008) Zinc in soils and crop nutrition. IZA and IFA, Brussels and Paris

Alloway BJ (2013) Heavy metals and metalloids as micronutrients for plants and animals. In: Alloway BJ (ed) Heavy metals in soils, 3rd edn. Springer, Dordrecht, pp 195-209. https://doi.org/10. 1007/978-94-007-4470-7

Ansari W, Chandanshive SU, Bhatt V, Nadaf AHB, Vats S, Katara JL, Sonah H, Deshmukh R (2020) Genome editing in cereals: approaches, applications and challenges. Int J Mol Sci 21:4040. https://doi.org/10.3390/ijms21114040

Appels R, Eversole K, Feuillet C, Keller B, Rogers J et al (2018) Shifting the limits in wheat research and breeding using a fully annotated reference genome. Science 361(6403). https://doi.org/10. 1126/science.aar7191

Aragão FJL, Barros LMG, De Sousa MV, Grossi de Sá MF, Almeida ERP, Gander ES, Rech EL (1999) Expression of a methioninerich storage albumin from the Brazil nut (Bertholletia excelsa HBK, Lecythidaceae) in transgenic bean plants (Phaseolus vulgaris L., Fabaceae). Genet Mol Biol 22:445-449

Aref F (2010) Zinc and boron fertilization on concentration and uptake of iron and manganese in the corn grain. Am J Sci 6:236-242

Arun M, Subramanyam K, Theboral J, Sivanandhan G, Rajesh M, Dev GK, Jaganath B, Manickavasagam M, Girija S, Ganapathi A (2014) Transfer and targeted overexpression of g-tocopherol methyltransferase (g-TMT) gene using seed-specific promoter improves tocopherol composition in Indian soybean cultivars. Appl Biochem Biotechnol 172:1763-1776. https://doi.org/10. 1007/s12010-013-0645-9

Assunção AG, Herrero E, Lin YF, Huettel B, Talukdar S, Smaczniak C, Immink RG, Eldik MV, Fiers M, Schat H, Aarts MG (2010) Arabidopsis thaliana transcription factors bZIP19 and bZIP23 regulate the adaptation to zinc deficiency. PNAS 107:1029610301. https://doi.org/10.1073/pnas.1004788107

Bae M, Kim H (2020) The role of vitamin C, vitamin D, and selenium in immune system against COVID-19. Molecules 25:5346. https://doi.org/10.3390/molecules25225346

Bagri DS, Upadhyaya DC, Kumar A, Upadhyaya CP (2018) Overexpression of PDX-II gene in potato (Solanum tuberosum L.) leads to the enhanced accumulation of vitamin B6 in tuber tissues and tolerance to abiotic stresses. Plant Sci 272:267-275. https://doi. org/10.1016/j.plantsci.2018.04.024

Bai C, Capell T, Berman J, Medina V, Sandmann G, Christou P, Zfu C (2016) Bottlenecks in carotenoid biosynthesis and accumulation in rice endosperm are influenced by the precursor-product balance. Plant Biotechnol J 14:195-205. https://doi.org/10.1111/ pbi. 12373

Bashir K, Rasheed S, Kobayashi T, Seki M, Nishizawa NK (2016) Regulating subcellular metal homeostasis: the key to crop improvement. Front Plant Sci 7:1192. https://doi.org/10.3389/ fpls.2016.01192

Bashir K, Nozoye T, Nagasaka S, Rasheed S, Miyauchi N, Seki M, Nakanishi H, Nishizawa NK (2017) Paralogs and mutants show that one DMA synthase functions in iron homeostasis in rice. $\mathrm{J}$ Exp Bot 68:1785-1795. https://doi.org/10.1093/jxb/erx065

Beal T, Massiot E, Arsenault JE, Smith MR, Hijmans RJ (2017) Global trends in dietary micronutrient supplies and estimated prevalence of inadequate intakes. PLoS One 12(4). https://doi.org/10.1371/ journal.pone. 0175554

Beasley JT, Bonneau JP, Sánchez-Palacios JT, Moreno-Moyano LT, Callahan DL, Tako E, Glahn RP, Lombi E, Johnson AA (2019) Metabolic engineering of bread wheat improves grain iron concentration and bioavailability. Plant Biotechnol J 17:1514-1526. https://doi.org/10.1111/pbi.13074

Beck MA, Shi Q, Morris VC, Levander OA (1995) Rapid genomic evolution of a non-virulent coxsackievirus B3 in selenium-deficient mice results in selection of identical virulent isolates. Nat Med 1:433-436. https://doi.org/10.1038/nm0595-433

Blancquaert D, Daele JV, Strobbe S, Kiekens F, Storozhenko S, Steur HD, Gellynck X, Lambert W, Stove C, Der Straeten DV (2015) Improving folate (vitamin B-9) stability in biofortified rice through metabolic engineering. Nat Biotechnol 33:1076-1078. https://doi.org/10.1038/nbt.3358

Bonneau J, O'Brien M, Plett DC, Johnson AA (2018) Genetic pathways important for iron nutrition and biofortification of bread wheat. Annu Rev Plant Biol:237-272.https://doi.org/10.1002/97811 19312994.apr0628

Boudiaf M, Messai Y, Bentouhami E, Schmutz M, Blanck C, Ruhlmann L, Bezzi H, Tairi L, Mekki DE (2021) Green synthesis of $\mathrm{NiO}$ nanoparticles using Nigella sativa extract and their enhanced electro-catalytic activity for the 4-nitrophenol degradation. J Phys Chem Solids 153:110020. https://doi.org/10. 1016/j.jpcs.2021.110020

Bouis HE, Saltzman A (2017) Improving nutrition through biofortification: a review of evidence from HarvestPlus, 2003 through 2016. Glob Food Sec 12:49-58. https://doi.org/10.1016/j.gfs. 2017.01.009

Brady NC, Weil RR (2002) The nature and properties of soils. Pearson Education, Upper Saddle River

Bratovcic A, Suljagic J (2019) Micro-and nano-encapsulation in food industry. Croat J Food Sci Technol 11:113-121. https://doi.org/ 10.17508/CJFST.2019.11.1.17

Briat JF, Duc C, Ravet K, Gaymard F (2010) Ferritins and iron storage in plants. Biochim Biophys Acta Gen Subj 1800:806-814. https://doi.org/10.1016/j.bbagen.2009.12.003

Budke C, Mühling KH, Daum D (2020) Iodine uptake and translocation in apple trees grown under protected cultivation. $\mathbf{J}$ Plant Nutr Soil Sci 183:468-481. https://doi.org/10.1002/jpln. 202000099

Cakmak I (2008) Enrichment of cereal grains with zinc: agronomic or genetic biofortification? Plant Soil 302:1-17. https://doi.org/10. 1007/s11104-007-9466-3

Cakmak I (2009) Enrichment of fertilizers with zinc: an excellent investment for humanity and crop production in India. J Trace Elem Med Biol 29:281-289. https://doi.org/10.1016/j.jtemb. 2009.05.002

Cakmak I, Kutman UÁ (2018) Agronomic biofortification of cereals with zinc: a review. Eur J Soil Sci 69:172-180. https://doi.org/ 10.1111/ejss. 12437

Cakmak I, Kalayci M, Kaya Y, Torun AA, Aydin N, Wang Y, Arisoy Z, Erdem H, Yazici A, Gokmen O, Ozturk L, Horst WJ (2010a) Biofortification and localization of zinc in wheat grain. J Agric Food Chem 58:9092-9102. https://doi.org/10.1021/jf101197h

Cakmak I, Pfeiffer WH, McClafferty B (2010b) Biofortification of durum wheat with zinc and iron. Cereal Chem 87:10-20. https:// doi.org/10.1094/CCHEM-87-1-0010

Cakmak I, Prom-u-thai C, Guilherme LRG, Rashid A, Hora KH, Yazici A, Savasli E, Kalayci M, Tutus L, Phuphong P, Rizwan M, Martins FAD, Dinali GS, Ozturk L (2017) Iodine biofortification of wheat, rice and maize through fertilizer strategy. Plant Soil 418:319-335. https://doi.org/10.1007/s11104-017-3295-9

Callaway E (2018) CRISPR plants now subject to tough GM laws in European Union. Nature 560:16-17. https://doi.org/10.1038/ d41586-018-05814-6

Cámara M, Sánchez-Mata MC, Fernández-Ruiz V, Cámara RM, Cebadera E, Domínguez L (2021) A review of the role of nicronutrients and bioactive compounds on immune system supporting to fight against the COVID-19. Dis Foods 10:1088. https:// doi.org/10.3390/foods10051088

Cardini A, Pellegrino E, White PJ, Mazzolai B, Mascherpa MC, Ercoli L (2021) Transcriptional regulation of genes involved in zinc uptake, sequestration and redistribution following foliar zinc 
application to Medicago sativa. Plants 10:476. https://doi.org/ $10.3390 /$ plants 10030476

CAST (Council for Agricultural Science and Technology) (2020) Food biofortification-reaping the benefits of science to overcome hidden hunger: a paper in the series on the need for agricultural innovation to sustainably feed the world by 2050 . Ames, Iowa. https://www.cast-science.org/wp-content/uploads/2020/ 10/CAST_IP69_Biofortification-1.pdf. Accessed 10 Oct 2021

Chaparro CM, Suchdev PS (2019) Anemia epidemiology, pathophysiology, and etiology in low-and middle-income countries. Ann N Y Acad Sci 1450:15-31. https://doi.org/10.1111/nyas.14092

Che P, Zhao ZY, Glassman K, Dolde D, Hu TX, Jones TJ, Gruis DF, Obukosia S, Wambugu F, Albertsen MC (2016) Elevated vitamin E content improves all-trans $\beta$-carotene accumulation and stability in biofortified sorghum. PNAS 113:11040-11045. https://doi. org/10.1073/pnas.1605689113

Choudhary AK, Suri VK (2014) Frontline demonstration programmean effective technology transfer tool for adoption of oilseeds production technology in Himachal Pradesh, India. Commun Soil Sci Plant Anal 45:1480-1498

Clapp J, Moseley WG (2020) This food crisis is different: COVID-19 and the fragility of the neoliberal food security order. J Peasant Stud 47:1393-1417. https://doi.org/10.1080/03066150.2020. 1823838

Colunga Biancatelli RML, Berrill M, Marik PE (2020) The antiviral properties of vitamin C. Expert Rev Anti-Infect Ther 18:99-101. https://doi.org/10.1080/14787210.2020.1706483

Connorton JM, Jones ER, Rodríguez-Ramiro I, Fairweather-Tait S, Uauy C, Balk J (2017) Wheat vacuolar iron transporter TaVIT2 transports $\mathrm{Fe}$ and $\mathrm{Mn}$ and is effective for biofortification. Plant Physiol 174:2434-2444. https://doi.org/10.1104/pp.17.00672

Conte SS, Walker EL (2011) Transporters contributing to iron trafficking in plants. Mol Plant 4:464-476. https://doi.org/10.1093/ $\mathrm{mp} / \mathrm{ssr} 015$

Cooper M, Greene-Finestone L, Lowell H, Levesque J, Robinson S (2012) Iron sufficiency of Canadians. Health Rep 23:41-48

Cronje C, George GM, Fernie AR, Bekker J, Kossmann J, Bauer R (2012) Manipulation of L-ascorbic acid biosynthesis pathways in Solanum lycopersicum: elevated GDP-mannose pyrophosphorylase activity enhances L-ascorbate levels in red fruit. Planta 235:553-564. https://doi.org/10.1007/s00425-011-1525-6

Cui HX, Sun CJ, Liu Q, Jiang J, Gu W (2010) Applications of nanotechnology in agrochemical formulation: perspectives, challenges and strategies, Int. conference on Nanoagri Sao pedro, Brazil. pp 105. http://www.fao.org/fileadmin/templates/agns/pdf/NANOA GRI_2010.pdf. Accessed 13 June 2021

Cun P, Sarrobert C, Richaud P, Chevalier A, Soreau P, Auroy P, Gravot A, Baltz A, Leonhardt N, Vavasseur A (2014) Modulation of $\mathrm{Zn} / \mathrm{Cd}$ P1B2-ATPase activities in Arabidopsis impacts differently on $\mathrm{Zn}$ and $\mathrm{Cd}$ contents in shoots and seeds. Metallomics 6:2109-2116. https://doi.org/10.1039/c4mt00182f

Curie C, Panaviene Z, Loulergue C, Dellaporta SL, Briat JF, Walker EL (2001) Maize yellow stripe1 encodes a membrane protein directly involved in Fe (III) uptake. Nature 409:346-349. https:// doi.org/10.1038/35053080

Dary O, Hurrell R (2006) Guidelines on food fortification with micronutrients. World Health Organization, Food and Agricultural Organization of the United Nations Geneva, Switzerland, 3-37. https://www.who.int/publications/i/item/9241594012. Accessed 29 Sept 2021

De Moura FF, Moursi M, Donahue Angel M, Angeles-Agdeppa I, Atmarita A, Gironella GM, Muslimatun S, Carriquiry A (2016) Biofortified $\beta$-carotene rice improves vitamin $\mathrm{A}$ intake and reduces the prevalence of inadequacy among women and young children in a simulated analysis in Bangladesh, Indonesia, and the Philippines. Am J Clin Nutr 104:769-775. https://doi.org/10. 3945/ajcn.115.129270

DeRosa M, Monreal CM, Schnitzer M, Walsh R, Sultan Y (2010) Nanotechnology in fertilizers. Nat Nanotechnol 5:91-91. https:// doi.org/10.1038/nnano.2010.2

De Steur H, Mehta S, Gellynck X, Finkelstein JL (2017) GM biofortified crops: potential effects on targeting the micronutrient intake gap in human populations. Curr Opin Biotechnol 44:181-188. https://doi.org/10.1016/j.copbio.2017.02.003

Derscheid RJ, Van Geelen A, Berkebile AR, Gallup JM, Hostetter SJ, Banfi B et al (2014) Increased concentration of iodide in airway secretions is associated with reduced respiratory syncytial virus disease severity. Am J Respir Cell Mol Biol 50:389-397. https://doi.org/10.1165/rcmb.2012-0529OC

Detterbeck A, Pongrac P, Rensch S, Reuscher S, Pečovnik M, Vavpetič P, Clemens S (2016) Spatially resolved analysis of variation in barley (Hordeum vulgare) grain micronutrient accumulation. New Phytol 211:1241-1254

Díaz-Benito P, Banakar R, Rodríguez-Menéndez S, Capell T, Pereiro R, Christou P, Abadía J, Fernández B, Álvarez-Fernández A (2018) Iron and zinc in the embryo and endosperm of rice (Oryza sativa L.) seeds in contrasting 2'-deoxymugineic acid/ nicotianamine scenarios. Front Plant Sci 9:1190. https://doi. org/10.3389/fpls.2018.01190

Domokos-Szabolcsy E, Alshaal T, Elhawat N, Abdalla N, Reis A, El-Ramady H (2017) The interactions between selenium, nutrients and heavy metals in higher plants under abiotic stresses. JENVBS 1(2017):5-31. https://doi.org/10.21608/JENVBS. 2017.951.1001

Dong OX, Ronald PC (2019) Genetic engineering for disease resistance in plants: recent progress and future perspectives. Plant Physiol 180:26-83. https://doi.org/10.1104/pp.18.01224

Dong W, Cheng ZJ, Lei CL, Wang XL, Wang L, Wang J, Wu FQ, Zhang X, Guo XP, Zhai HQ, Wan JM (2014) Overexpression of folate biosynthesis genes in rice (Oryza sativa L.) and evaluation of their impact on seed folate content. Plants Foods Hum Nutr 69:379-385. https://doi.org/10.1007/s11130-014-0450-9

Dong OX, Yu S, Jain R, Zhang N, Duong PQ, Butler C, Li Y, Lipzen A, Martin JA, Barry KW, Schmutz J, Tian L, Ronald PC (2020) Marker-free carotenoid-enriched rice generated through targeted gene insertion using CRISPR-Cas9. Nat Commun 11:1-10. https://doi.org/10.1038/s41467-020-14981-y

Dotaniya M, Meena V, Basak B, Meena RS (2016) Potassium uptake by crops as well as microorganisms. In: Meena VS, Maurya BR, Verma JP, Meena RS (eds) Potassium solubilizing microorganisms for sustainable agriculture, 1 st edn. Springer, India, pp 267-280. https://doi.org/10.1007/978-81-322-2776-2_19

Dunwell JM (2014) Transgenic cereals: current status and future prospects. J Cereal Sci 59:419-434. https://doi.org/10.1016/j. jcs.2013.08.008

ECA, European Commission on Agriculture (2015) Addressing social and economic burden of malnutrition through nutritionsensitive agricultural and food policies in the region of Europe and Central Asia. Thirty-ninth session. http://www.fao.org/3/ mo398e/mo398e.pdf. Accessed 18 June 2021

El-Ramady H, Abdalla N, Elbasiouny H, Elbehiry F, Elsakhawy T, Omara AED, Amer M, Bayoumi Y, Shalaby TA, Eid Y, ZiaurRehman M (2021) Nano-biofortification of different crops to immune against COVID-19: a review. Ecotoxicol Environ Saf:112500. https://doi.org/10.1016/j.ecoenv.2021.112500

Endo A, Saika H, Takemura M, Misawa N, Toki S (2019) A novel approach to carotenoid accumulation in rice callus by mimicking the cauliflower Orange mutation via genome editing. Rice 12:1-5. https://doi.org/10.1186/s12284-019-0345-3

FAO, IFAD, UNICEF, WFP, WHO (2020) The State of Food Security and Nutrition in the World 2020. Transforming food 
systems for affordable healthy diets, Rome. Accessed 29 Sept 2021. https://doi.org/10.4060/ca9692en

FAO (2016) Soil portal: Management of calcareous soils. http:// www.fao.org/soils-portal/soil-management/management-ofsome-problem-soils/calcareous-soils/en/. Accessed $20 \mathrm{Sept}$ 2021

FAO (2017) Food and Agriculture Organization, The Future of Food and Agriculture, Trends and Challenges; Food and Agriculture Organization, Rome. http://www.fao.org/3/i6583e/i6583e.pdf. Accessed 13 June 2021

FAO (2019) The stateof food security and nutrition in trhe world. http:// www.fao.org/3/ca5162en/ca5162en.pdf. Accessed 29 Sept 2021

FAO (2020a) The State of Security and Nutrition in the World. http:// www.fao.org/3/ca9692en/online/ca9692en.html\#tab1. Accessed 18 June 2021

FAO (2020b) FAOSTAT database. Food and Agriculture Organization of the United Nations, Rome. http://www.fao.org/faostat/ en/\#home. Accessed 13 June 2021

Feil B (2001) Phytic acid. J New Seeds 3:1-35. https://doi.org/10.1300/ J153v03n03_01

Feng R, Wei C, Tu S (2013) The roles of selenium in protecting plants against abiotic stresses. Environ Exp Bot 87:58-68. https://doi. org/10.1016/j.envexpbot.2012.09.002

Gadd GM (2010) Metals, minerals and microbes: geomicrobiology and bioremediation. Microbiology 156(3):609-643. https://doi.org/ 10.1099/mic.0.037143-0

García MJ, Lucena C, Romera FJ, Alcántara E, Pérez-Vicente R (2010) Ethylene and nitric oxide involvement in the up-regulation of key genes related to iron acquisition and homeostasis in Arabidopsis. J Exp Bot 61:3885-3899. https://doi.org/10.1093/jxb/erq203

García MJ, Romera FJ, Lucena C, Alcántara E, Pérez-Vicente R (2015) Ethylene and the regulation of physiological and morphological responses to nutrient deficiencies. Plant Physiol 169:51-60. https://doi.org/10.1104/pp.15.00708

Garg M, Sharma N, Sharma S, Kapoor P, Kumar A, Chunduri V, Arora P (2018) Biofortified crops generated by breeding, agronomy, and transgenic approaches are improving lives of millions of people around the world. Front Nutr 5:12. https://doi.org/10.3389/ fnut.2018.00012

Gashgari R, Selim S, Abdel-Mawgoud M, Warrad M, Habeeb TH, Saleh AM, AbdElgawad H (2020) Arbuscular mycorrhizae induce a global metabolic change and improve the nutritional and health benefits of pennyroyal and parsley. Acta Physiol Plant 42:1-11. https://doi.org/10.1007/s11738-020-03091-3

Gastélum-Estrada A, Serna-Saldívar SO, Jacobo-Velázquez DA (2021) Fighting the COVID-19 pandemic through biofortification: innovative approaches to improve the immunomodulating capacity of foods. ACS Food Sci Technol 1:480-486. https://doi.org/10. 1021/acsfoodscitech.1c00019

Gharsallaoui A, Roudaut G, Chambin O, Voilley A, Saurel R (2007) Applications of spray-drying in microencapsulation of food ingredients: an overview. Food Res Int 40:1107-1121. https:// doi.org/10.1016/j.foodres.2007.07.004

Giri A, Heckathorn S, Mishra S, Krause, (2017) Heat stress decreases levels of nutrient-uptake and-assimilation proteins in tomato roots. Plants 6:6. https://doi.org/10.3390/plants6010006

Gombart AF, Pierre A, Maggini SA (2020) A review of micronutrients and the immune system-working in harmony to reduce the risk of infection. Nutrients 12:236. https://doi.org/10.3390/nu12010236

Goredema-Matongera N, Ndhlela T, Magorokosho C, Kamutando CN, Van Biljon A, Labuschagne M (2021) Multinutrient biofortification of maize (Zea mays L.) in Africa: current status, opportunities and limitations. Nutrients 13:1039. https://doi.org/10.3390/ nu13031039

Graham AW (2004) Effects of zinc nutrition and high temperature on the growth, yield and grain quality of wheat (Triticum aestivum
L.), Doctoral dissertation. https://digital.library.adelaide.edu. $\mathrm{au} /$ dspace/bitstream/2440/37982/10/02whole.pdf. Accessed 29 Sept 2021

Gupta RK, Gangoliya SS, Singh NK (2015) Reduction of phytic acid and enhancement of bioavailable micronutrients in food grains. J Food Sci Technol 52:676-684. https://doi.org/10.1007/ s13197-013-0978-y

Gupta S, Brazier AKM, Lowe NM (2020) Zinc deficiency in low-and middle-income countries: prevalence and approaches for mitigation. J Hum Nutr Diet 33:624-643. https://doi.org/10.1111/ jhn.12791

Halka M, Smolen S, Czernicka M, Klimek-Chodacka M, Pitala J, Tutaj K (2019) Iodine biofortification through expression of HMT, SAMT and S3H genes in Solanum lycopersicum L. Plant Physiol Biochem 144:35-48. https://doi.org/10.1016/j.plaphy. 2019.09

Hansen TH, Lombi E, Fitzgerald M, Laursen KH, Frydenvang J, Husted S, Boualaphanh C, Resurreccion A, Howard DL, de Jonge MD, Paterson D, Schjoerring JK (2012) Losses of essential mineral nutrients by polishing of rice differ among genotypes due to contrasting grain hardness and mineral distribution. J Cereal Sci 56:307-315. https://doi.org/10.1016/j. jcs.2012.07.002

Hasanuzzaman M, Hossain MA, Fujita M (2010) Selenium in higher plants: physiological role, antioxidant metabolism and abiotic stress tolerance. J Plant Sci 5:354-375. https://doi.org/10.3923/ jps.2010.354.375

He L, Zhao J, Wang L, Liu Q, Fan Y, Li B, Yu YL, Chen C, Li YF (2021) Using nano-selenium to combat coronavirus disease 2019 (COVID-19)? Nano Today 36:101037. https://doi.org/ 10.1016/j.nantod.2020.101037

Heckathorn SA, Giri A, Mishra S, Bista D (2014) Heat stress and roots. In: Tuteja N, Gill S (eds) Climate change and plant abiotic stress tolerance. Wiley Blackwell, Weinheim, pp 109-136

Hindt MN, Guerinot ML (2012) Getting a sense for signals: regulation of the plant iron deficiency response. BBA Mol Cell Res 1823:1521-1530. https://doi.org/10.1016/j.bbamcr.2012.03.010

Hindu V, Palacios-Rojas N, Babu R, Suwarno WB, Rashid Z, Usha R, Saykhedkar GR, Nair SK (2018) Identification and validation of genomic regions influencing kernel zinc and iron in maize. Theor Appl Genet 131:1443-1457. https://doi.org/10.1007/ s00122-018-3089-3

Hiradate S, Ma JF, Matsumoto H (2007) Strategies of plants to adapt to mineral stresses in problem soils. In: Sparks J (ed) Advances in agronomy. Academic Press, Elsevier, Cambridge, pp 65-132. https://doi.org/10.1016/S0065-2113(07)96004-6

Hirschi KD (2009) Nutrient biofortification of food crops. Annu Rev Nutr 29:401-421. https://doi.org/10.1146/annur ev-nutr-080508-141143

Horton S, Mannar V, Wesley A (2008) Best practice paper: food fortification with iron and iodine, Copenhagen Consensus Center, Copenhagen Business School, Denmark. https://www.copen hagenconsensus.com/sites/default/files/bpp_fortification.pdf. Accessed 13 June 2021

Hsu FC, Wirtz M, Heppel S, Bogs J, Kramer U, Khan MS, Bub A (2011) Generation of Se-fortified broccoli as functional food: impact of Se fertilization on S metabolism. Plant Cell Environ 34:192-207. https://doi.org/10.1111/j.1365-3040.2010.02235.x http://www.harvestzinc.org/. Accessed 2 March 2021

Hu BF, Shao S, Ni H, Fu ZY, Hu LS, Zhou Y, Min XX, She SF, Chen SC, Huang MX, Zhou L, Li Y, Shi Z (2020) Current status, spatial features, health risks, and potential driving factors of soil heavy metal pollution in China at province level. Environ Pollut 266:114961. https://doi.org/10.1016/j.envpol.2020.114961

Huang M, Zhu Y, Li Z, Huang B, Luo N, Liu C, Zeng G (2016) Compost as a soil amendment to remediate heavy metal contaminated 
agricultural soil: mechanisms, eficacy, problems, and strategies. Water Air Soil Pollut 227:359-376. https://doi.org/10.1007/ s11270-016-3068-8

Huang S, Sasaki A, Yamaji N, Okada H, Mitani-Ueno N, Ma JF (2020) The ZIP transporter family member OsZIP9 contributes to root zinc uptake in rice under zinc-limited conditions. Plant Physiol 183:1224-1234. https://doi.org/10.1104/pp.20.00125

Huizar MI, Arena R, Laddu DR (2021) The global food syndemic: the impact of food insecurity, malnutrition and obesity on the healthspan amid the COVID-19 pandemic. Prog Cardiovasc Dis 64:105. https://doi.org/10.1016/j.pcad.2020.07.002

Humphrey OS, Young SD, Bailey EH, Crout NMJ, Ander EL, Hamilton EM, Watts MJ (2019) Iodine uptake, storage and translocation mechanisms in spinach (Spinacia oleracea L.). Environ Geochem Health 41:2145-2156. https://doi.org/10.1007/ s10653-019-00272-z

Huo C, Ouyang J, Yang H (2014) CuO nanoparticles encapsulated inside Al-MCM-41 mesoporous materials via direct synthetic route. Sci Rep 4:1-9. https://doi.org/10.1038/srep03682

Imtiaz M, Rashid A, Khan P, Memon MY, Aslam M (2010) The role of micronutrients in crop production and human health. Pak $\mathrm{J}$ Bot 42:2565-2578

Ishimaru Y, Takanashi R, Bashir K, Shimo H, Senoura T, Sugimoto K, Ono K, Yano M, Ishikawa S, Arao T, Nakanashi H, Nishizawa NK (2012) Characterizing the role of rice NRAMP5 in manganese, iron and cadmium transport. Sci Rep 2:286. https://doi.org/10.1038/srep00286

Ivanov R, Brumbarova T, Bauer P (2012) Fitting into the harsh reality: regulation of iron-deficiency responses in dicotyledonous plants. Mol Plant 5:27-42. https://doi.org/10.1093/mp/ssr065

Jaganathan D, Ramasamy K, Sellamuthu G, Jayabalan S, Venkataraman G (2018) CRISPR for crop improvement: an update review. Front Plant Sci 9:971-985. https://doi.org/10.3389/ fpls.2018.00985

Jewell CP, Zhang SV, Gibson MJS, Tovar-Méndez A, Mcclure B, Moyle LC (2020) Intraspecific genetic variation underlying postmating reproductive barriers between species in the wild tomato clade (Solanum sect. Lycopersicon). J Hered 111:216226. https://doi.org/10.1101/718544

Jha AB, Warkentin TD (2020) Biofortification of pulse crops: status and future perspectives. Plants 9:73. https://doi.org/10.3390/ plants9010073

Kalra T, Tomar PC, Arora K (2020) Micronutrient encapsulation using nanotechnology: nanofertilizers. Plant Arch 20:1748-1753

Kang YJ, Shim KC, Lee HS, Jeon YA, Kim SH, Kang JW, Yun YT, Park IK, Ahn SN (2018) Fine mapping and candidate gene analysis of the quantitative trait locus gw8. 1 associated with grain length in rice. Genes Genom 40:389-397. https://doi.org/ 10.1007/s13258-017-0640-6

Karimi P, Khavari-Nejad RA, Niknam V, Ghahremaninejad F, Najafi F (2012) The effects of excess copper on antioxidative enzymes, lipid peroxidation, proline, chlorophyll, and concentration of $\mathrm{Mn}, \mathrm{Fe}$, and $\mathrm{Cu}$ in Astragalus neo-mobayenii. Sci World J. https://doi.org/10.1100/2012/615670

Karunaratne DN, Siriwardhana DAS, Ariyarathna IR, Rajakaruna RMPI, Banu FT, Karunaratne V (2017) Nutrient delivery through nanoencapsulation. In: Grumezescu AM (ed) Nutrient delivery. Academic Press, Elsevier, Cambridge, pp 653-680. https://doi.org/10.1016/B978-0-12-804304-2.00017-2

Kaur T, Rana KL, Kour D, Sheikh I, Yadav N, Yadav AN, Kumar V, Yadav AN, Dhaliwal HS, Saxena AK, Saxena AK (2020) Microbe-mediated biofortification for micronutrients: present status and future challenges. In: Rastegari AA, Yadav $\mathrm{N}$, Yadav AN (eds) New and future development in microbial biotecnology and bioengineering. Elsevier, pp 1-17. https:// doi.org/10.1016/B978-0-12-820528-0.00002-8

Kehoe L, Walton J, Flynn A (2019) Nutritional challenges for older adults in Europe: current status and future directions. Proc Nutr Soc 78:221-233. https://doi.org/10.1017/S0029665118002744

Kieliszek M, Lipinski B (2020) Selenium supplementation in the prevention of coronavirus infections (COVID-19). Med Hypotheses 143:109878. https://doi.org/10.1016/j.mehy.2020.109878

Kim MJ, Kim JK, Kim HJ, Pak JH, Lee JH, Kim DH, Choi HK, Jung HW, Le JD, Chung YS, Ha SH (2012) Genetic modification of the soybean to enhance the $\beta$-carotene content through seedspecific expression. PLoS ONE 7:e48287. https://doi.org/10. 1371/journal.pone.0048287

Klassen S, Murphy S (2020) Equity as both a means and an end: lessons for resilient food systems from COVID-19. World Dev 136:105104. https://doi.org/10.1016/j.worlddev.2020.105104

Kobayashi T, Nishizawa NK (2012) Iron uptake, translocation, and regulation in higher plants. Annu Rev Plant Biol 63:131-152. https://doi.org/10.1146/annurev-arplant-042811-105522

Kumar A, Choudhary AK, Pooniya V, Suri VK, Singh U (2016) Soil factors associated with micronutrient acquisition in crops-biofortification perspective. In: Singh U, Praharaj CS, Singh SS, Singh NP (eds) Biofortification of food crops, 1st edn. Springer, New Delhi, pp 159-176. https://doi.org/10.1007/978-81-3222716-8_13

Kumar S, Palve A, Joshi C, Srivastava RK (2019) Crop biofortification for iron $(\mathrm{Fe})$, zinc $(\mathrm{Zn})$ and vitamin A with transgenic approaches. Heliyon 5:e01914. https://doi.org/10.1016/j.heliy on.2019.e01914

Kumssa DB, Joy EJ, Ander EL, Watts MJ, Young SD, Walker S, Broadley MR (2015) Dietary calcium and zinc deficiency risks are decreasing but remain prevalent. Sci Rep 5:1-11. https://doi.org/ 10.1038/srep10974

Laborde D, Martin W, Swinnen J, Vos R (2020) COVID-19 risks to global food security. Science 369:500-502. https://doi.org/10. 1126/science.abc4765

Landa P (2021) Positive effects of metallic nanoparticles on plants: overview of involved mechanisms. Plant Physiol Biochem 161:12-24. https://doi.org/10.1016/j.plaphy.2021.01.039

Landini M, Gonzali S, Perata P (2011) Iodine biofortification in tomato. J Plant Nutr Soil Sci 174:480-486. https://doi.org/10. 1002/jpln.201000395

Lee S, An G (2009) Over-expression of OsIRT1 leads to increased iron and zinc accumulations in rice. Plant Cell Environ 32:408-416. https://doi.org/10.1111/j.1365-3040.2009.01935.x

Lee S, Chiecko JC, Kim SA, Walker EL, Lee Y, Guerinot ML, An G (2009) Disruption of OsYSL15 leads to iron inefficiency in rice plants. Plant Physiol 150:786-800. https://doi.org/10.1104/pp. 109.135418

Lema M (2018) Marker assisted selection in comparison to conventional plant breeding. Agric Res Technol 14:555914. https://doi. org/10.19080/ARTOAJ.2018.14.555914

Li L, Yang Y, Xu Q, Owsiany K, Welsch R, Chitchumroonchokchai C, Lu S, Eck JV, Deng XX, Failla M, Thannhauser TW (2012) The Or gene enhances carotenoid accumulation and stability during post-harvest storage of potato tubers. Mol Plant 5:339-352. https://doi.org/10.1093/mp/ssr099

Li KT, Moulin M, Mangel N, Albersen M, Verhoeven-Duif NM, Ma Q, Zhang P, Fitzpatrick TB, GruissemVanderschuren WH (2015) Increased bioavailable vitamin B6 in field-grown transgenic cassava for dietary sufficiency. Nat Biotechnol 33:1029-1032

Li YL, Chen WP, Yang YP, Wang TQ, Liu CF, Cai B (2020) Heavy metal pollution characteristics and comprehensive risk evaluation of farmland across the eastern plain of Jiyuan City. Acta Sci Circumst 40:2229-2236 
Li S, Zhou X, Chen J, Chen R (2018) Is there a strategy I iron uptake mechanism in maize? Plant Signal Behav 13.https://doi.org/10. 1080/15592324.2016.1161877

Liang Q, Wang K, Liu X, Riaz B, Jiang L, Wan X, Ye X, Zhang C (2019) Improved folate accumulation in genetically modified maize and wheat. J Exp Bot 70:1539-1551. https://doi.org/10. 1093/jxb/ery 453

Lilay GH, Persson D, Castro PH, Liao F, Alexander R, Aarts MG, Assuncao AG (2020) The Arabidopsis bZIP19 and bZIP23 transcription factors act as zinc-sensors to control plant zinc status. BioRxiv. https://doi.org/10.1101/2020.06.29.177287

Listgarten J, Weinstein M, Kleinstiver BP, Sousa AA, Joung JK, Crawford J, Gao K, Hoang L, Elibol M, Doench JG (2018) Prediction of off-target activities for the end-to-end design of CRISPR guide RNAs. Nat Biom Eng 2:38-47. https://doi.org/10.1038/ s41551-017-0178-6

Liu H, Zhang J, Christie P, Zhang F (2008) Influence of iron plaque on uptake and accumulation of Cd by rice (Oryza sativa L.) seedlings grown in soil. Sci Total Environ 394:361-368. https://doi. org/10.1016/j.scitotenv.2008.02.004

Liu Z, Cheng R, Xiao W, Guo Q, Wang N (2014) Effect of off-season flooding on growth, photosynthesis, carbohydrate partitioning, and nutrient uptake in Distylium chinense. PLoS ONE 9:e107636. https://doi.org/10.1371/journal.pone.0107636

Liu C, Chen G, Li Y, Peng Y, Zhang A, Hong K et al (2017) Characterization of a major QTL for manganese accumulation in rice grain. Sci Rep 7:1-17. https://doi.org/10.1038/s41598-017-18090-7

Lönnerdal B, Bryant A (2006) Absorption of iron from recombinant human lactoferrin in young US women. AJMS 83:305-309. https://doi.org/10.1093/ajcn/83.2.305

Low JW, Mwanga ROM, Andrade M, Carey E, Ball AM (2017) Tackling vitamin A deficiency with biofortified sweetpotato in subSaharan Africa. Glob Food Sec 14:23-30. https://doi.org/10. 1016/j.gfs.2017.01.004

Lyons GH, Lewis J, Lorimer MF, Holloway RE, Brace DM, Stangoulis JC, Graham RD (2004) High-selenium wheat: agronomic biofortification strategies to improve human nutrition. Food Agric Environ 2:171-178

Madhaiyan M, Poonguzhali S, Kwon SW, Sa TM (2010) Bacillus methylotrophicus sp. nov., a methanol-utilizing, plant-growthpromoting bacterium isolated from rice rhizosphere soil. Int $\mathbf{J}$ Syst Evol Microbiol 60:2490-2495. https://doi.org/10.1099/ijs.0. 015487-0

Mai HJ, Pateyron S, Bauer P (2016) Iron homeostasis in Arabidopsis thaliana: transcriptomic analyses reveal novel FIT-regulated genes, iron deficiency marker genes and functional gene networks. BMC Plant Biol 16:1-22. https://doi.org/10.1186/ s12870-016-0899-9

Malik KA, Maqbool A (2020) Transgenic crops for biofortification. Front Sustain Food Syst 4:182. https://doi.org/10.3389/fsufs. 2020.571402

Mareedu T, Poiba VR, Vangalapati M (2021) Green synthesis of iron nanoparticles by green tea and black tea leaves extract. Mater Today Proc 42:1498-1501. https://doi.org/10.1016/j.matpr.2021. 01.444

Marques E, Darby HM, Kraft J (2021) Benefits and limitations of nontransgenic micronutrient biofortification approaches. Agronomy 11:464. https://doi.org/10.3390/agronomy11030464

Marschner H, Romheld V, Kissel M (1986) Different strategies in higher plants in mobilization and uptake of iron. Plant Nutr 9:695-713. https://doi.org/10.1080/01904168609363475

Martin JAR, Arias ML, Corbi JMG (2006) Heavy metals contents in agricultural topsoils in the Ebro basin (Spain). Application of the multivariate geostatistical methods to study spatial variations.
Environ Pollut 144:1001-1012. https://doi.org/10.1016/j.envpol. 2006.01.045

Masarovičová E, Králová K (2012) Plant-heavy metal interaction: phytoremediation, biofortification and nanoparticles. In: Montanaro $\mathrm{G}$ (ed) Advances in selected plant physiology aspects. InTech, Rijeka, pp 75-102. https://doi.org/10.57772/33722

Masuka B, Magorokosho C, Olsen M, Atlin GN, Bänziger M, Pixley KV, Vivek BS, Labuschagne M, Matemba-Mutasa R, Burgueño J, Macrobert J, Prasanna BM, Das B, Makumbi D, Tarekegne A, Crossa J, Zaman-Allah M, van Bilijon A, Cairns JE (2017) Gains in maize genetic improvement in eastern and southern Africa: II. CIMMYT open-pollinated variety breeding pipeline. Crop Sci 57:180-191. https://doi.org/10.2135/cropsci2016.05.0408

McGrath SP, Chambers BJ, Taylor MJ, Carlton-Smith CH (2012) Biofortification of zinc in wheat grain by the application of sewage sludge. Plant Soil 361:97-108. https://doi.org/10.1007/ s11104-012-1381-6

Meena VS, Maurya BR, Verma JP (2014) Does a rhizospheric microorganism enhance $\mathrm{K}+$ availability in agricultural soils? Microbiol Res 169:337-347. https://doi.org/10.1016/j.micres.2013.09.003

Minx P, Cordum H, Wilson R et al (2005) Sequence, annotation, and analysis of synteny between rice chromosome 3 and diverged grass species. Genome Res 15:1284-1291. https://doi.org/10. 1101/gr.3869505

Molvig L, Tabe LM, Eggum BO, Moore AE, Craig S, Spencer Di Higgins TJ (1997) Enhanced methionine levels and increased nutritive value of seeds of transgenic lupins (Lupinus angustifolius L.) expressing a sunflower seed albumin gene. PNAS 94:8393-8398. https://doi.org/10.1073/pnas.94.16.8393

Monreal CM, DeRosa M, Mallubhotla SC, Bindraban PS, Dimkpa CO (2015) Nanotechnologies for increasing the crop use efficiency of fertilizer-micronutrients. Biol Fertil Soils 52:423-437. https:// doi.org/10.1007/s00374-015-1073-5

Moraghan JT, Mascagni HJ Jr (1991) Environmental and soil factors affecting micronutrient deficiencies and toxicities. Micronutrients Agric 4:371-425. https://doi.org/10.2136/sssabookser4.2ed. c11

Moreno-Jiménez E, Plaza C, Saiz H, Manzano R, Flagmeier M, Maestre FT (2019) Aridity and reduced soil micronutrient availability in global drylands. Nat Sustain 2:371-377. https://doi.org/10. 1038/s41893-019-0262-x

Myers SS, Zanobetti A, Kloog I, Huybers P, Leakey AD, Bloom AJ, Carlisle E, Dietterich LH, Fitzgerald G, Hasegawa T, Holbrook NM, Nelson RL, Ottman MJ, Raboy V, Sakai H, Sartor KA, Schwartz J, Seneweera S, Tausz M, Usui Y (2014) Increasing $\mathrm{CO}_{2}$ threatens human nutrition. Nature 510:139-142. https://doi. org/10.1038/nature13179

Naeem M, Majeed S, Hoque MZ, Ahmad I (2020) Latest developed strategies to minimize the off-target effects in CRISPR-Casmediated genome editing. Cells 9:1608. https://doi.org/10.3390/ cells 9071608

Narayanan N, Beyene G, Chauhan RD, Gaitán-Solís E, Gehan J, Butts P, Siritunga G, Okwuonu I, Woll A, Jiménez-Aguilar DM, Boy E, Grusak MA, Anderson P, Taylor NJ (2019) Biofortification of field-grown cassava by engineering expression of an iron transporter and ferritin. Nat Biotechnol 37:144-151. https://doi.org/ 10.1038/s41587-018-0002-1

Neenu S, Ramesh K (2020) Weather-micronutrient interactions in soil and plants-a critical review. Chem Sci Rev Lett. https://doi.org/ 10.37273/chesci.CS20510136

Newman R, Waterland N, Moon Y, Tou JC (2019) Selenium biofortification of agricultural crops and effects on plant nutrients and bioactive compounds important for human health and disease prevention-a review. Plant Foods Hum Nutr 74:449-460. https:// doi.org/10.1007/s11130-019-00769-Z 
Nozoye T, Kim S, Kakei Y, Takahashi M, Nakanishi H, Nishizawa NK (2014) Enhanced levels of nicotianamine promote iron accumulation and tolerance to calcareous soil in soybean. Biosci Biotechnol Biochem 78:1677-1684. https://doi.org/10.1080/09168 451.2014.936350

Nozoye T, Otani M, Senoura T, Nakanishi H, Nishizawa NK (2017) Overexpression of barley nicotianamine synthase 1 confers tolerance in the sweet potato to iron deficiency in calcareous soil. Plant Soil 418:75-88. https://doi.org/10.1007/ s11104-016-3134-4

Nunez S, Arets E, Alkemade R, Verwer C, Leemans R (2019) Assessing the impacts of climate change on biodiversity: is below 2 C enough? Clim Change 154:351-365. https://doi.org/10.1007/ s10584-019-02420-x

Nussaume L, Kanno S, Javot H, Marin E, Nakanishi TM, Thibaud MC (2011) Phosphate import in plants: focus on the PHT1 transporters. Front Plant Sci 2:83. https://doi.org/10.3389/fpls.2011.00083

Ozturk L, Yazici MA, Yucel C, Torun A, Cekic C, Bagci A, Ozkan H, Braun HC, Sayers Z, Cakmak I (2006) Concentration and localization of zinc during seed development and germination in wheat. Physiol Plant 128:144-152. https://doi.org/10.1111/j. 1399-3054.2006.00737.x

Palta Ş, Demir S, Şengönül K, Kara Ö, Şensoy H (2010) Arbüsküler Mikorizal funguslar (AMF) bitki ve toprakla ilişkileri, mera islahındaki önemleri. Bartın Orman Fakültesi Dergisi 12:87-98

Philipo M, Ndakidemi PA, Mbega ER (2021) Importance of common bean genetic zinc biofortification in alleviating human zinc deficiency in sub-Saharan Africa. Cogent Food Agric 7:1907954. https://doi.org/10.1080/23311932.2021.1907954

Pooniya V, Shivay YS (2015) Influence of green manuring and zinc fertilization on quality parameters of Basmati rice. Commun Soil Sci Plant Anal 46:382-392. https://doi.org/10.1080/00103624. 2014.981275

Pourcel L, Moulin M, Fitzpatrick TB (2013) Examining strategies to facilitate vitamin B1 biofortification of plants by genetic engineering. Front Plant Sci 4:160. https://doi.org/10.3389/fpls.2013. 00160

Prentice AM, Gershwin ME, Schaible UE, Keusch GT, Victora CG, Gordon JI (2008) New challenges in studying nutrition-disease interactions in the developing world. J Clin Investig 118:13221329. https://doi.org/10.1172/JCI34034

Qiao K, Wang F, Liang S, Wang H, Hu Z, Chai T (2019) New biofortification tool: wheat TaCNR5 enhances zinc and manganese tolerance and increases zinc and manganese accumulation in rice grains. J Agric Food Chem 67:9877-9884. https://doi.org/10. 1021/acs.jafc.9b04210

Qin X, Fischer K, Yu S, Dubcovsky J, Tian L (2016) Distinct expression and function of carotenoid metabolic genes and homoeologs in developing wheat grains. BMC Plant Biol 16:155. https://doi. org/10.1186/s12870-016-0848-7

Rana KL, Kour D, Yadav N, Yadav AN (2020) Endophytic microbes in nanotechnology: current development, and potential biotechnology applications. In: Kumar A, Singh VK (eds) Microbial endophytes. Woodhead Publishing, Cambridge, MA, pp 231-262. https://doi.org/10.1016/B978-0-12-818734-0.00010-3

Rengel Z (2000) Uptake and transport of manganese in plants. In: Sigel A, Sigel H (eds) Metal 1ons in biological systems. Marcel Dekker, New York, pp 57-87

Resmi R, Yoonus J, Beena B (2021) A novel greener synthesis of ZnO nanoparticles from Nilgiriantusciliantus leaf extract and evaluation of its biomedical applications. Mater Today Proc 46:30623068. https://doi.org/10.1016/j.matpr.2021.02.498

Richardson DP, Lovegrove JA (2021) Nutritional status of micronutrients as a possible and modifiable risk factor for COVID-19: a UK perspective. Br J Nutr 125:678-684. https://doi.org/10.1017/ S000711452000330X
Rodó X, San-José A, Kirchgatter K, López L (2021) Changing climate and the COVID-19 pandemic: more than just heads or tails. Nat Med 27:576-579. https://doi.org/10.1038/s41591-021-01303-y

Rostami M, Movahedi Z, Davari MR, Siahpoosh S (2017) Effect of foliar application of biofertilizer and nano-fertilizers on morphophysiological characteristics of peppermint (Mentha piperita L.). In: Tielkes E (ed) Tropentag-Future agriculture: social-ecological transitions and bio-cultural shifts. Malayer University, Iran, p 536

Samad N, Dutta S, Sodunke TE, Fairuz A, Sapkota A, Miftah ZF, Haque M (2021) Fat-soluble vitamins and the current global pandemic of COVID-19: evidence-based efficacy from literature review. J Inflamm Res 14:2091

Sarwar N, Malhi SS, Zia MH, Naeem A, Bibi S, Farid G (2010) Role of mineral nutrition in minimizing cadmium accumulation by plants. J Sci Food Agric 90:925-937. https://doi.org/10.1002/ jsfa.3916

Sasaki A, Yamaji N, Yokosho K, Ma JF (2012) Nramp5 is a major transporter responsible for manganese and cadmium uptake in rice. Plant Cell 24:2155-2167. https://doi.org/10.1105/tpc.112. 096925

Savo V, Lepofsky D, Benner JP, Kohfeld KE, Bailey J, Lertzman K (2016) Observations of climate change among subsistence-oriented communities around the world. Nat Clim Chang 6:462473. https://doi.org/10.1038/NCLIMATE2958

Schiavon M, Nardi S, dalla Vecchia F, Ertani A (2020) Selenium biofortification in the 21st century: status and challenges for healthy human nutrition. Plant Soil 453:245-270. https://doi.org/10. 1007/s11104-020-04635-9

Schmidt MA, Parrott WA, Hildebrand DF, Berg RH, Cooksey A, Pendarvis K, He Y, Mccarthy F, Herman EM (2015) Transgenic soya bean seeds accumulating $\beta$-carotene exhibit the collateral enhancements of oleate and protein content traits. Plant Biotechnol J 13:590-600. https://doi.org/10.1111/pbi.12286

Sedeek KEM, Mahas A, Mahfouz M (2019) Plant genome engineering for targeted improvement of crop traits. Front Plant Sci 10:114. https://doi.org/10.3389/fpls.2019.00114

Senoura T, Shimo H, Ishikawa S, Nishizawa NK (2011) The OsNRAMP1 iron transporter is involved in $\mathrm{Cd}$ accumulation in rice. J Exp Bot 62:4843-4850. https://doi.org/10.1093/jxb/err136

Senoura T, Sakashita E, Kobayashi T, Takahashi M, Aung MS, Masuda H, Nakanishi H, Nishizawa NK (2017) The iron-chelate transporter OsYSL9 plays a role in iron distribution in developing rice grains. Plant Mol Biol 95:375-387. https://doi.org/10.1007/ s11103-017-0656-y

Shahzad Z, Rouached H, Rakha A (2014) Combating mineral malnutrition through iron and zinc biofortification of cereals. Compr Rev Food Sci Food Saf 13:329-346. https://doi.org/10.1111/ 1541-4337.12063

Shariatipour N, Heidari B (2020) Genetic-based biofortification of staple food crops to meet zinc and iron deficiency-related challenges. In: Aftap T, Hakeem KR (eds) Plant micronutrients, 1st edn. Springer, Cham, pp 173-223

Sharifi R, Mohammadi K, Rokhzadi A (2016) Effect of seed priming and foliar application with micronutrients on quality of forage corn (Zea mays). Environ Exp Biol 14:151-156. https://doi.org/ 10.22364/eeb.14.21

Sharma A, Johri BN, Sharma AK, Glick BR (2003) Plant growth-promoting bacterium Pseudomonas sp. strain GRP3 influences iron acquisition in mung bean (Vigna radiata L. Wilzeck). Soil Biol Biochem 38:887-894. https://doi.org/10.1016/S0038-0717(03) 00119-6

Sharma V, Saini DK, Kumar A, Kaushik PA (2019) Review of 1mportant QTLs for biofortification traits in rice. Preprints. https://doi.org/10.20944/preprints201912.0158.v1

Shekari F, Mohammadi H, Pourmohammad A, Avanes A, Benam MBK (2015) Spring wheat yielding and the content of protein and zinc 
in its grain depending on zinc fertilisation. Electron J Pol Agric Univ 18:1-12

Sherwin JC, Reacher MH, Dean WH, Ngondi J (2012) Epidemiology of vitamin A deficiency and xerophthalmia in at-risk populations. Trans R Soc Trop Med Hyg 106:205-214. https://doi.org/ 10.1016/j.trstmh.2012.01.004

Shiva Krishna G, Suma K (2019) Gene editing nucleases-ZFNs, TALENS and CRISPR: a review. Chettinad Health City Med J 8:130135. https://doi.org/10.36503/chcmj8(4)-06

Singh SP, Gruissem W, Bhullar NK (2017) Single genetic locus improvement of iron, zinc and beta-carotene content in rice grains. Sci Rep 7:1-11. https://doi.org/10.1038/ s41598-017-07198-5

Slamet-Loedin IH, Johnson-Beebout SE, Impa S, Tsakirpaloglou N (2015) Enriching rice with $\mathrm{Zn}$ and $\mathrm{Fe}$ while minimizing Cd risk. Front Plant Sci 6:121. https://doi.org/10.3389/fpls.2015.00121

Smith MR, Myers SS (2018) Impact of anthropogenic $\mathrm{CO}_{2}$ emissions on global human nutrition. Nat Clim Chang 8:834-839. https:// doi.org/10.1038/s41558-018-0253-3

Smith MR, Myers SS (2019) Global health implications of nutrient changes in rice under high atmospheric carbon dioxide. GeoHealth 3:190-200. https://doi.org/10.1029/2019GH000188

Song W, Lee HS, Jin SR, Ko D, Martinoia E, Lee Y, An G, Ahn S (2015) Rice PCR1 influences grain weight and $\mathrm{Zn}$ accumulation in grains. Plant Cell Environ 38:2327-2339. https://doi.org/10. 1111/pce. 12553

Song XY, Zhu WJ, Tang RM, Cai JH, Chen M, Yang Q (2016) Overexpression of $S t L C Y b$ increases $\beta$-carotene accumulation in potato tubers. Plant Biotechnol Rep 10:95-104. https://doi.org/ 10.1007/s11816-016-0390-y

Sooriyaarachchi P, Jeyakumar DT, King N, Jayawardena R (2021) Impact of vitamin D deficiency on COVID-19. Clin Nutr ESPEN 44:372-378. https://doi.org/10.1016/j.clnesp.2021.05.011

Stevens GA, Bennett JE, Hennocq Q, Lu Y, De-Regil LM, Rogers L, Danaei G, Li G, White RA, Flaxman SR, Oehrle SP, Finucane MM, Guerro R, Bhutta ZA, Paulino AT, Fawzi W, Black RE, Ezzati M (2015) Trends and mortality effects of vitamin A deficiency in children in 138 low-income and middle-income countries between 1991 and 2013: a pooled analysis of populationbased surveys. Lancet Global Health 3:e528-e536. https://doi. org/10.1016/S2214-109X(15)00039-X

Stewart CP, Dewey KG, Ashoran P (2010) The undernutrition epidemic: an urgent health priority. Lancet 375:282. https://doi.org/ 10.1016/S0140-6736(10)60132-8

Stomph TJ, Choi EY, Stangoulis JCR (2011) Temporal dynamics in wheat grain zinc distribution: is sink limitation the key? Ann Bot 107:927-937. https://doi.org/10.1093/aob/mcr040

Strobbe S, De Lepeleire J, Van Der Straeten D (2018) From in planta function to vitamin-rich food crops: the ACE of biofortification. Front Plant Sci 9:1862. https://doi.org/10.3389/fpls.2018.01862

Subbaiah LV, Prasad TN, Krishna TG, Sudhakar P, Reddy BR, Pradeep $\mathrm{T}$ (2016) Novel effects of nanoparticulate delivery of zinc on growth, productivity, and zincbiofortification in maize (Zea mays L.). J Agric Food Chem 64:3778-3788. https://doi.org/10.1021/ acs.jafc.6b00838

Takahashi R, Bashir K, Ishimaru Y, Nishizawa NK, Nakanishi H (2012) The role of heavy-metal ATPases, HMAs, in zinc and cadmium transport in rice. Plant Signal Behav 7:1605-1607. https://doi.org/10.4161/psb.22454

Takahashi R, Ishimaru Y, Shimo H, Bashir K, Senoura T, Sugimoto K, Ono K, Suzui N, Kawachi N, Ishii S, Yin YG, Fujimaki S, Yano M, Nishizawa NK, Nakanishi H (2014) From laboratory to field: OSNRAMP5-knockdown rice is a promising candidate for Cd phytoremediation in paddy fields. PLoS ONE 9:e98816. https://doi.org/10.1371/journal.pone.0098816
Tan S, Han R, Li P, Yang G, Li S, Zhang P, Wang WB, Zhao WZ, Yin LP (2015) Over-expression of the MxIRT1 gene increases iron and zinc content in rice seeds. Transgenic Res 24:109-122. https://doi.org/10.1007/s11248-014-9822-Z

Tang L, Mao B, Li Y, Lv Q, Zhang L, Chen C, He H, Wang W, Zeng X, Shao Y, Pan Y, Hu Y, Peng Y, Fu X, Li H, Xia S, Zhao B (2017) Knockout of OsNramp5 using the CRISPR/Cas9 system produces low $\mathrm{Cd}$-accumulating indica rice without compromising yield. Sci Rep 7:1-12. https://doi.org/10.1038/ s41598-017-14832-9

Tejada-Jiménez M, Chamizo-Ampudia A, Galván A, Fernández E, Llamas Á (2013) Molybdenum metabolism in plants. Metallomics 5:1191-1203. https://doi.org/10.1039/c3mt00078h

Tiong J, McDonald GK, Genc Y, Pedas P, Hayes JE, Toubia J (2014) HvZIP7 mediates zinc accumulation in barley (Hordeum vulgare) at moderately high zinc supply. New Phytol 201:131-143. https:// doi.org/10.1111/nph.12468

Trijatmiko KR, Dueñas C, Tsakirpaloglou N, Torrizo L, Arines FM, Adeva C, Balindong J, Oliva N, Sapasap MV, Borrero J, Rey J, Francisco P, Nelson A, Nakanishi H, Lombi E, Tako E, Glahn RP, Stangoulis J, Chadha-Mohanty P, Johnson AAT, Tohme J, Barry G, Slamet-Loedin IH (2016) Biofortified indica rice attains iron and zinc nutrition dietary targets in the field. Sci Rep 6:1-13. https://doi.org/10.1038/srep19792

Tsai SQ, Zheng Z, Nguyen NT, Liebers M, Topkar VV, Thapar V, Wyvekens N, Khayter C, Iafrate AJ, Le LP (2015) GUIDEseq enables genome-wide profiling of off-target cleavage by CRISPR-Cas nucleases. Nat Biotechnol 33:187-197. https:// doi.org/10.1038/nbt.3117

Uddin M, Fukuta Y (2020) A region on chromosome 7 related to differentiation of rice (Oryza sativa L.) between lowland and upland ecotypes. Front Plant Sci 11:1135. https://doi.org/10.3389/fpls. 2020.01135

UNEP (2021) Food systems hold key to ending world hunger. https:// www.unep.org/news-and-stories/story/food-systems-hold-keyending-world-hunger. Accessed 29 Sept 2021

Uraguchi S, Fujiwara T (2012) Cadmium transport and tolerance in rice: perspectives for reducing grain cadmium accumulation. Rice 5:1-8. https://doi.org/10.1186/1939-8433-5-5

Van Der Straeten D, Bhullar NK, De Steur H, Gruissem W, MacKenzie D, Pfeiffer W, Bouis H (2020) Multiplying the efficiency and impact of biofortification through metabolic engineering. Nat Commun 11:1-10. https://doi.org/10.1038/s41467-020-19020-4

Verheesen RH, Traksel RAM (2020) Iodine, a preventive and curative agent in the COVID-19 pandemic? Med Hypotheses 144:109860. https://doi.org/10.1016/j.mehy.2020.10986

Verma PK, Verma S, Chakrabarty D, Pandey N (2021) Biotechnological approaches to enhance zinc uptake and utilization efficiency in cereal crops. J Soil Sci Plant Nutr:1-13.https://doi.org/10. 1007/s42729-021-00532-x

Vert G, Briat JF, Curie C (2001) Arabidopsis IRT2 gene encodes a root-periphery iron transporter. Plant J 26:181-189. https://doi. org/10.1046/j.1365-313x.2001.01018.x

Vestergaard G, Garrett RA, Shah SA (2014) CRISPR adaptive immune systems of Archaea. RNA Biol 11:156-167. https://doi.org/10. 4161/rna.27990

Vlcko T, Ohnoutkova L (2019) Recent advances and perspectives in crop biofortification. Biol Plant 63:586-593

Voortman RL, Bindraban PS (2015) Beyond N and P: towards a land resource ecology perspective and impactful fertilizer interventions in Sub-Sahara Africa. VFRC Reports 2015/1, Virtual Fertilizer Research Center, Wanshington

Wairich A, de Oliveira BHN, Arend EB, Duarte GL, Ponte LR, Sperotto RA, Ricachenevsky FK, Fett JP (2019) The combined strategy for iron uptake is not exclusive to domesticated 
rice (Oryza sativa). Sci Rep 9:1-17. https://doi.org/10.1038/ s41598-019-52502-0

Wakeel A, Farooq M, Bashir K, Ozturk L (2018) Plant micronutrient use efficiency. In: Houssain MA, Kamiya T, Phan Tran LS, Fujiwara T (eds) Micronutrient malnutrition and biofortification: recent advances and future perspectives. Academic, pp 225-243 https://doi.org/10.1016/B978-0-12-812104-7.00017-4

Wang P, Menzies NW, Lombi E, McKenna BA, Johannessen B, Glover CJ, Kopittke PM (2013) Fate of ZnO nanoparticles in soils and cowpea (Vigna unguiculata). Environ Sci Technol 47:1382213830. https://doi.org/10.1021/es403466p

Wang C, Zeng J, Li Y, Hu W, Chen L, Miao Y (2014) Enrichment of provitamin A content in wheat (Triticum aestivum L.) by introduction of the bacterial carotenoid biosynthetic genes $\mathrm{CrtB}$ and CrtI. J Exp Bot 65:2545-2556. https://doi.org/10.1093/jxb/ eru138

Wang P, Wang H, Liu Q, Tian X, Shi Y, Zhang X (2017) QTL mapping of selenium content using a RIL population in wheat. PLoS ONE 12:e0184351. https://doi.org/10.1371/journal.pone.0184351

Wang N, Qiu W, Dai J, Guo X, Lu Q, Wang T, Li S, Liu T, Zuo Y (2019) AhNRAMPl enhances manganese and zinc uptake in plants. Front Plant Sci 10:415. https://doi.org/10.3389/fpls.2019. 00415

Wessells KR, Brown KH (2012) Estimating the global prevalence of zinc deficiency: results based on zinc availability in national food supplies and the prevalence of stunting. PLoS ONE 7:e50568. https://doi.org/10.1371/journal.pone.0050568

Wessels I, Rink L (2020) Micronutrients in autoimmune diseases: possible therapeutic benefits of zinc and vitamin D. J Nutri Biochem 77:108240. https://doi.org/10.1016/j.jnutbio.2019.108240

White PJ, Broadley MR (2009) Biofortification of crops with seven mineral elements often lacking in human diets-iron, zinc, copper, calcium, magnesium, selenium and iodine. New Phytol 182:4984. https://doi.org/10.1111/j.1469-8137.2008.02738.x

WHO, UNICEF (2017) Report of the Fourth Meeting of the WHOUNICEF Technical Expert Advisory group on nutrition Monitoring (TEAM). Geneva, Switzerland. https://cdn.who.int/media/ docs/default-source/nutritionlibrary/team---technical-expertadvisory-group-on-nutrition-monitoring/meeting-reports/2017team-4thmeeting-report.pdf?sfvrsn=268b5d69_4\&download $=$ true. Accessed 13 June 2021

WHO (2019) Anaemia in women of reproductive age, Anaemia in children $<5$ years. https://www.who.int/data/gho/data/indicators/ indicator-details/GHO/prevalence-of-anaemia-in-women-ofrep roductive-age-(-). https://www.who.int/data/gho/data/indicators/ indicator-details/GHO/prevalence-of-anaemia-inchildren-under5-years-(-). Accessed 10 May 2021

WHO (2020) New electronic survey manual supports countries to combat micronutrient deficiencies. https://www.who.int/publicatio ns/i/item/9789240012691. Accessed 18 July 2021

WHO (2021) Anemia. https://www.who.int/health-topics/anaemia\#. Accessed 13 June 2021

WHO, World Health Organization (2007) Preventing and controlling micronutrient deficiencies in populations affected by an emergency. https://www.who.int/docs/default-source/nutritionl ibrary/preventing-and-controlling-micronutrient-deficiencies-inpopulations-affected-by-an-emergency.pdf?sfvrsn=e17f6dff_2. Accessed 29 Sept 2021

WHO, World Health Organization (2009) Global health risks. Mortality and burden of disease attributable to selected major risks. Switzerland, Geneva. 60 p. https://apps.who.int/iris/handle/ 10665/44203. Accessed 13 June 2021

Wirth J, Poletti S, Aeschlimann B, Yakandawala N, Drosse B, Osorio S, Tohge T, Fernie AR, Günther D, Gruissem W, Sautter C (2009) Rice endosperm iron biofortification by targeted and synergistic action of nicotianamine synthase and ferritin. Plant Biotechnol J 7:631-644. https://doi.org/10.1111/j.1467-7652.2009.00430.x

World Bank (2020) Global economic prospects, Washington, DC. http://hdl.handle.net/10986/33748. Accessed 29 Sept 2021

Wu J, Maehara T, Shimokawa T, Yamamoto S, Harada C, Takazaki Y, Ono N, Mukai Y, Koike K, Yazaki J, Fujii F, Shomura A, Ando T, Kono I, Waki K, Yamamoto K, Yano M, Matsumoto T, Sasaki T (2002) A comprehensive rice transcript map containing 6591 expressed sequence tag sites. Plant Cell 14:525-535. https://doi. org/10.1105/tpc.010274

Wu TY, Gruissem W, Bhullar NK (2018) Facilitated citrate-dependent iron translocation increases rice endosperm iron and zinc concentrations. Plant Sci 270:13-22. https://doi.org/10.1016/j.plant sci.2018.02.002

Yadav AN (2020) Plant microbiomes for sustainable agriculture. In: Yaday AN, Singh J, Rastegari AA, Yadav N (eds) Plant microbiomes for sustainable agriculture: current research and future challenges, 1st edn. Springer İnternational, Cham, pp 475-482. https://doi.org/10.1007/978-3-030-38453-1_16

Yang M, Zhang Y, Zhang L, Hu J, Zhang X, Lu K, Dong H, Wang D, Zhao FJ, Huang CF, Lian X (2014) OsNRAMP5 contributes to manganese translocation and distribution in rice shoots. J Exp Bot 65:4849-4861. https://doi.org/10.1093/jxb/eru259

Yao BM, Chen P, Sun GX (2020) Distribution of elements and their correlation in bran, polished rice, and whole grain. Food Sci Nutr 8:982-992. https://doi.org/10.1002/fsn3.1379

Ye X, Al-Babili S, Klöti A, Zhang J, Lucca P, Beyer P, Potrykus I (2000) Engineering the provitamin A ( $\beta$-carotene) biosynthetic pathway into (carotenoid-free) rice endosperm. Science 287:303-305. https://doi.org/10.1126/science.287.5451.303

Ye L, Li L, Wang L, Wang S, Li S, Du J, Zhang S, Shou H (2015) MPK3/MPK6 are involved in iron deficiency-induced ethylene production in Arabidopsis. Front Plant Sci 6:953. https://doi.org/ 10.3389/fpls.2015.00953

Yokosho K, Yamaji N, Ma JF (2016) OsFRDL1 expressed in nodes is required for distribution of iron to grains in rice. J Exp Bot 67:5485-5494. https://doi.org/10.1093/jxb/erw314

Yuvaraj M, Subramanian KS (2014) Controlled release fertilizer of zinc encapsulated by a manganese hollow core shell. Soil Sci Plant Nutr 61:319-326. https://doi.org/10.1080/00380768.2014. 979327

Zeng J, Wang X, Miao Y, Wang C, Zang C, Chen X, Li M, Li X, Wang Q, Li K, Chang J, Wang Y, Yang G, He G (2015) Metabolic engineering of wheat provitamin A by simultaneously overexpressing $\mathrm{CrtB}$ and silencing carotenoid hydroxylase (TaHYD). J Agric Food Chem 63:9083-9092. https://doi.org/10.1021/acs. jafc. 5 b04279

Zhang C, Liu J, Zhang Y, Cai X, Gong P, Zhang J, Wang T, Li H, Ye Z (2011) Overexpression of SlGMEs leads to ascorbate accumulation with enhanced oxidative stress, cold, and salt tolerance in tomato. Plant Cell Rep 30:389-398. https://doi.org/10.1007/ s00299-010-0939-0

Zhang L, Luo Y, Zhu Y, Zhang L, Zhang W, Chen R, Xu M, Fan Y, Wang L (2013) GmTMT2a from soybean elevates the $\alpha$-tocopherol content in corn and Arabidopsis. Transgenic Res 22:1021-1028. https://doi.org/10.1007/s11248-013-9713-8

Zhang C, Lu W, Yang Y, Shen Z, Ma JF, Zheng L (2018a) OsYSL16 is required for preferential $\mathrm{Cu}$ distribution to floral organs in rice. Plant Cell Physiol 59:2039-2051. https://doi.org/10.1093/ pcp/pcy 124

Zhang C, Shinwari KI, Luo L, Zheng L (2018b) OsYSL13 is involved in iron distribution in rice. Int J Mol Sci 19:3537. https://doi.org/ 10.3390/ijms 19113537

Zhang YY, Wu W, Liu H (2019) Factors affecting variations of soil pH in different horizons in hilly regions. PLoS ONE 14:e0218563. https://doi.org/10.1371/journal.pone.0218563 
Zhang J, Taylor EW, Bennett K, Saad R, Rayman MP (2020) Association between regional selenium status and reported outcome of COVID-19 cases in China. Am J Clin Nutr 111:1297-1299. https://doi.org/10.1093/ajcn/nqaa095

Zhang L, Luo Y, Liu B, Zhang L, Zhang W, Chen R, Wang L (2020) Overexpression of the maize $\gamma$-tocopherol methyltransferase gene (ZmTMT) increases $\alpha$-tocopherol content in transgenic Arabidopsis and maize seeds. Transgenic Res 29:95-104. https://doi.org/ 10.1007/s11248-019-00180-Z

Zimmermann MB (2009) Iodine deficiency. Endocr Rev 30:376-408. https://doi.org/10.1210/er.2009-0
Zimmermann MB, Jooste PL, Pandav CS (2008) Iodine-deficiency disorders. Lancet 372(9645):1251-1262. https://doi.org/10.1016/ S0140-6736(08)61005-3

Publisher's Note Springer Nature remains neutral with regard to jurisdictional claims in published maps and institutional affiliations. 